Научная статья

УДК 94(439)"1760-1800"

https://doi.org/10.23859/2587-8344-2021-5-2-2

Жолт Кёкенеши
Университет им. Л. Этвеша
Будапешт, Венгрия
kokenyesi.zsolt@ btk.elte.hu; https://orcid.org/0000-0003-3964-1043
Zsolt Kökenyesi
Eötwös Loránd University
Budapest, Hungary
kokenyesi.zsolt@btk.elte.hu; https://orcid.org/0000-0003-3964-1043

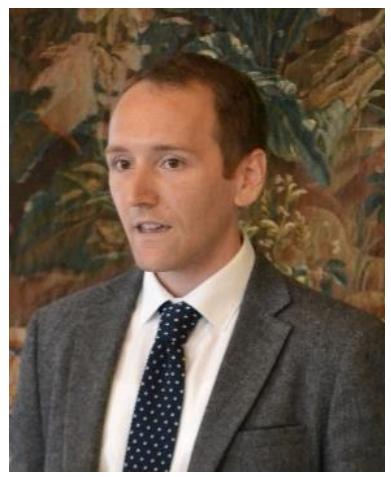

Служба и учеба: венгерская дворянская лейб-гвардия
как культурно-просветительский институт в Вене XVIII в. *

\title{
Service and education: the Royal Hungarian Bodyguard as a cultural institution in eighteenth-century Vienna
}

Аннотация. Венгерская дворянская лейб-гвардия, основанная в 1760 г., стала первой при венском дворе, рекрутировавшейся по территориальному принципу и исключительно из дворян. Она служила трем целям: существенно повысить присутствие венгров при дворе, репрезентировать монарха (власть государя) и венгерские сословия и обеспечить культурное пространство для молодых венгерских дворян. Для них лейб-гвардия стала подспорьем в выстраивании патрон-клиентских отношений и ориентировании в придворной среде, что особенно справедливо для выходцев из восточной Венгрии и Трансильванского княжества, а также для дворян-протестантов. В статье рассматривается роль лейб-гвардии в расширении культурных горизонтов молодых венгерских дворян, для чего наряду с известными источниками используются новые, такие как ранние проекты учреждения лейб-гвардии или

* Для цитирования: Кёкенеши Ж. Служба и учеба: венгерская дворянская лейб-гвардия как культурно-просветительский институт в Вене XVIII в. // Historia provinciae - журнал региональной истории. - 2021. - Т. 5. - № 2. - С. 393-432. DOI: 10.23859/2587-8344-2021-5-2-2

For citation: Kökenyesi, Zs. "Service and education: the Royal Hungarian Bodyguard as a cultural institution in eighteenth-century Vienna." Historia Provinciae - the Journal of Regional History, vol. 5, no. 2 (2021): 393-432, http://doi.org/10.23859/2587-8344-2021-5-2-2

(C) Кёкенеши Ж., 2021

(C) Kökenyesi Zs., 2021 
школьные матрикулы, привлекается внимание международного научного сообщества к социокультурному значению этого института. В начале статьи дан обзор ранних проектов учреждения лейб-гвардии, затем описаны принципы ее функционирования, наконец, на нескольких характерных примерах показана роль лейб-гвардии в карьерах венгерских магнатов и дворян.

Ключевые слова: Габсбургский двор, венгерское дворянство, Мария Терезия, рыцарская академия, подготовка офицеров, просвещенный абсолютизм, дворянское образование.

Abstract. The Royal Hungarian Bodyguard, founded in 1760, was the first guard unit at the Viennese court to be recruited on a territorial basis and exclusively from noblemen. The establishment of the Guard served three purposes: to significantly increase the presence of Hungarians at court, to represent the monarch (the power of the sovereign) and the Hungarian estates, and to provide a cultural space for young Hungarian noblemen. For them, the Guard became an aid in building patron-client relations and in orientation in the court environment, which was especially important for the natives of eastern Hungary and the Principality of Transylvania as well as for Protestant noblemen. The article examines the role of the Guard in expanding the cultural horizons of young Hungarian nobles. The purpose of the paper is to present the role of the guard as an instrument of education and acculturation of Hungarian nobles against the background of wellknown and recently discovered sources, such as guard establishment proposals, school register books and so forth, and to awaken interest of international research to the importance of this special institution. At the beginning of the article, an overview of the early proposals of the establishment of the Guard is given, then the principles of its operation are described, and finally, several examples are given to illustrate the role of the Guard in the careers of Hungarian magnates and noblemen.

Key words: Habsburg court, Hungarian nobility, Maria Theresa, knight academy, officer training, enlightened absolutism, noble education

Благодарности: Исследование выполнено при финансовой поддержке венгерского Национального комитета по исследованиям, развитию и инновациям, проект NKFIH PD № 132018 «Воспитанники-аристократы в сети иезуитских школ в Венгерском королевстве и Трансильвании в XVII-XVIII вв.».

Выражаю признательность Ольге Хавановой за идею написания статьи и ее перевод на русский язык.

Acknowledgements: The National Research, Development and Innovation Office of Hungary supported this research, Project NKFIH PD No 132018 "Aristocratic Students in the Jesuit School Network in the Kingdom of Hungary and Transylvania in the $17^{\text {th }}-18^{\text {th }}$ Centuries."

I would like to thank Olga Khavanova for the idea of writing this article and for translating it into Russian. 
В прежние времена княжеские гвардии были далеко не такими многочисленными, как в наши дни, в крайнем случае, в распоряжении государя были собственные, созданные для этой цели, разного характера и достоинства отряды ${ }^{1}$.

Эти строки, написанные в середине XVIII в., принадлежат знаменитому немецкому юристу и публицисту Фридриху Карлу фон Мозеру (1723-1798). Создание в 1760 г. венгерской дворянской лейб-гвардии прекрасно вписывается в нарисованную им картину. В это время при крупных европейских дворах количество и штат гвардий заметно возросли, и венский двор здесь не был исключением. Если в XVI-XVII вв. в имперской столице действовало только две гвардии (“Hartschiere” и “Trabanten"), насчитывавшие около 100 чел., то во второй трети XVIII в. были годы, когда параллельно службу несли шесть гвардейских соединений общей численностью личного состава 400-500 чел. ${ }^{2}$

Главными отличительными чертами венгерской дворянской лейб-гвардии, как следует из названия, были ее «венгерский» и «дворянский» характер. При венском дворе только она формировалась по территориальному принципу. Это роднило ее со швейцарской гвардией, формирования которой, начиная с XVIXVII вв., создавались повсюду в Европе ${ }^{3}$. Появление дворянских гвардий можно назвать одной из особенностей европейской придворной культуры XVIII в.: едва ли не одновременно похожими формированиями обзавелись курфюрст Август II Сильный в Дрездене, герцог Эрнст Август в Веймаре и герцог Эберхард Людвиг в Вюртемберге ${ }^{4}$. Создание дворянских гвардий в равной мере отвечало интересам владетельных князей и сословий. С одной стороны, исполнение обязанностей гвардейца квалифицировалось как военная служба, что прекрасно вписывалось в традиционный этос дворянского сословия, соответствовало его представлениям о призвании; с другой стороны,

${ }^{1}$ Moser F.C., von. Teutsches Hof-Recht: in zwölf Büchern. - Frankfurt; Leipzig: Johann Benjamin Andrea, 1754. - Bd. 1. - S. 224.

2 О функциях и принципах действия гвардий см.: Cerman I. Habsburgischer Adel und Aufklärung. Bildungsverhalten des Wiener Hofadels im 18. Jahrhundert. - Stuttgart: Franz Steiner Verlag, 2010. - S. 133-136 (Contubernium. Tübinger Beiträgezur Universitäts- und Wissenschaftsgeschichte. Bd. 72.); Rakuscha G. Die Leibgarden am österreichischen Herrscherhof: $\mathrm{PhD}$ diss. - University of Vienna, 1981 (рукопись); Urrisk-Obertyński R.M. Die k. u. k. Leibgarden am österreichisch-ungarischen Hof 1518-1918. - Gnas: Weishaupt, 2004. - S. 43-258.

${ }^{3}$ При дворе герцога Лотарингского в 1699 г. создали гвардию, укомплектованную солдатами из швейцарского кантона Люцерн. В 1737 г., когда герцог Франц обменял Лотарингию на Тоскану, они последовали за ним во Флоренцию, а после его коронации императором Священной Римской империи во Франкфурте-на-Майне в 1745 г. переселились в Вену. См.: Urrisk-Obertyński R.M. Die k. u. k. Leibgarden. - S. 53-56.

${ }^{4}$ Moser F.C. Teutsches Hof-Recht. - S. 237-238. 
этот институт помогал молодым дворянам обзавестись связями и в перспективе получить должность при дворе. Для правителя учреждение дворянской гвардии заметно увеличивало блеск двора, не в последнюю очередь усиливало легитимность власти. В Вене венгерская лейб-гвардия стала первым формированием, состоявшим исключительно из дворян, затем в 1763 г. к ней добавилось лейб-гвардейское соединение "Arcièren" при наследнике римскоимператорского престола - римском короле 5 .

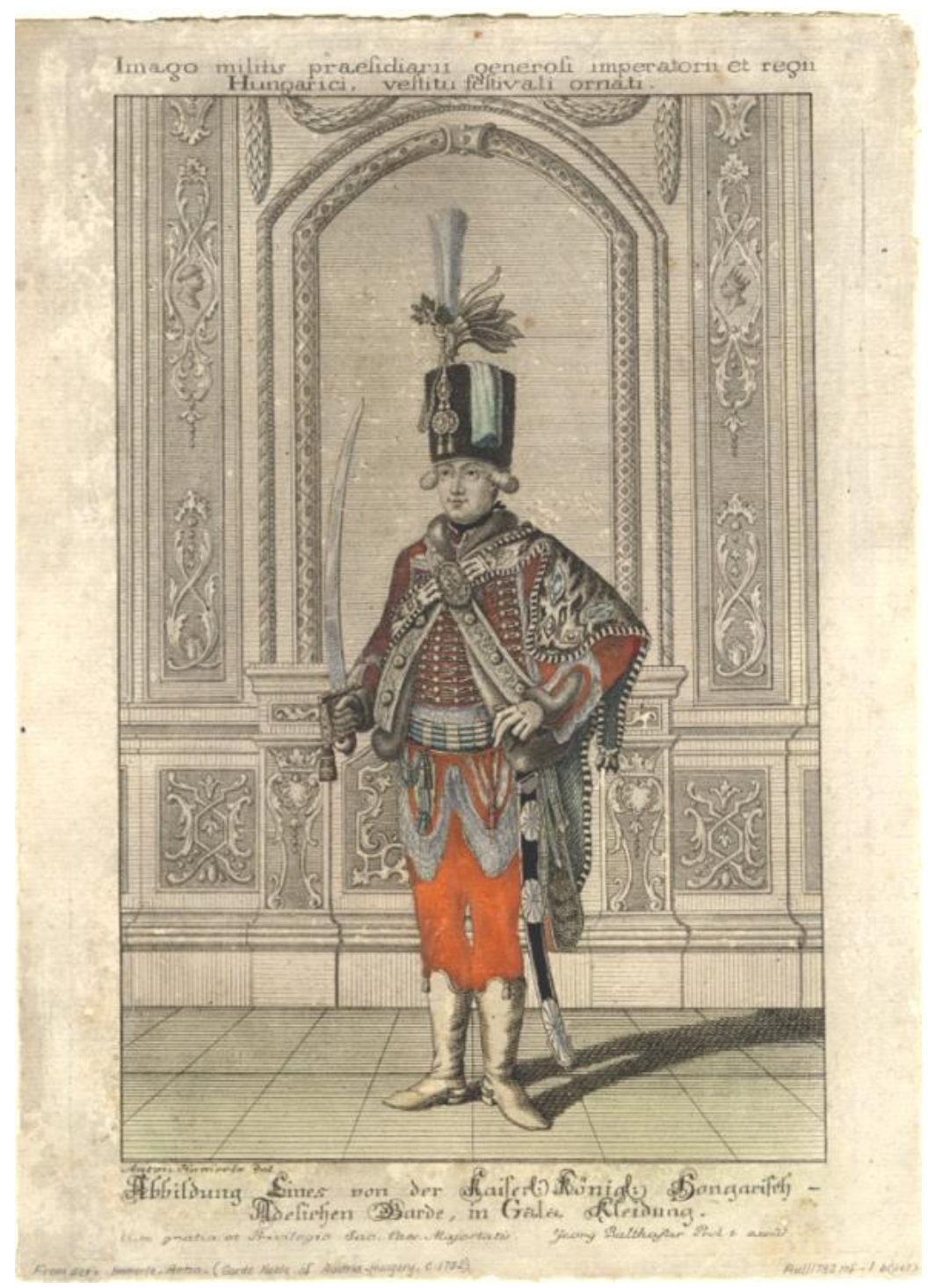

А. Хамерле. Изображение гвардейца императорско-королевской венгерской дворянской лейб-гвардии в парадной униформе.

Источник: Brown University Library, Digital Repository. URL: https://repository.library.brown.edu/studio/item/bdr:225656/

5 Paskovits E. Die erste Arcièrenleibgarde Seiner Majestät des Kaisers und Königs. Ein Rückblick auf ihre 150-jährige Geschichte. - Wien: Selbstverlag der k. k. Ersten Arcièrenleibgarde, 1914. 
Венгерская дворянская гвардия довольно хорошо исследована как в венгерской, так и в австрийской историографии ${ }^{6}$, но для лучшего понимания принципов функционирования этого института, особенно для читательской аудитории в других странах, следует прояснить ряд вопросов. В данной статье, в том числе с привлечением материала ранее неизвестных источников, будет показана роль лейб-гвардии как института передачи дворянской культуры. Преимущественное внимание предполагается уделить побудительным мотивам учреждения лейб-гвардии, ее функционированию, роли дворянской лейбгвардии в жизни и карьере отдельных гвардейцев.

\section{Учреждение и цели}

Идея учреждения венгерской дворянской гвардии появилась задолго до 1760 г. Первое из известных упоминаний об институте с подобными функциями относится к 1711-1712 гг., времени подписания Сатмарского мира, завершившего развернувшуюся в Венгерском королевстве параллельно с войной за Испанское наследство антигабсбургскую Освободительную войну под предводительством князя Ференца II Ракоци (1703-1711 гг.), и тем самым открывшего новую страницу в истории взаимоотношений венгров и Габсбургов ${ }^{7}$. Анонимный автор - по всей видимости, вхожий в придворные круги католик - в меморандуме, адресованном венским властям, изложил взгляды на причины, приведшие к восстанию Ракоци, и возможные пути для достижения долгосрочной консолидации ${ }^{8}$ Вторым пунктом в ряду предлагаемых мер стояло учреждение венгерской «гвардии», или кадетского

${ }^{6}$ Не претендуя на полноту изложения, упомяну лишь несколько работ: Ballagi A. A magyar királyi testőrség története, különös tekintettel irodalmi müködésére [История венгерской дворянской лейб-гвардии с особым вниманием к литературному творчеству]. Pest: Légrády testvérek, 1872; A magyar testőrségek névkönyve 1760-1918 [Именная книга венгерских лейб-гвардий 1760-1918] / Szerk. K. Tisza-Beői Hellenbronth. - Budapest: Stádium, [1940]; Urrisk-Obertyński R.M. Die k. u. k. Leibgarden. - S. 57-94.

7 Szijártó I. The Rákóczi Revolt as a Successful Rebellion // Resistance, Rebellion and Revolution in Hungary and Central Europe: Commemorating 1956 / ed. by L. Péter, M. Rady. London: Hungarian Cultural Centre London, 2008. - P. 67-76.

8 Magyar Nemzeti Levéltár Országos Levéltára, Budapest [Венгерский национальный государственный архив, далее - MNL OL]. Családi fondok. Levéltárak [Семейные фонды, архивы]. Kollonics család [Род Коллоничей]. - P 1901 I. s. d. - Nr. 13. Меморандум озаглавлен: "Reflexiones. Woher die Zeitherige Rebellion in Königreich Hungarn entstanden und wie disemmalokünfftig ab und dem Lande in besten Stand wieder zu haltensey“ [«Размышления. Откуда взялось недавнее восстание в Венгерском королевстве и как в будущем не допустить этого зла и вернуть страну к прежнему благосостоянию»]. Оригинал на немецком языке опубликован в: Kökényesi Zs. Helyzetértékelés és konszolidációs javaslatok. Egy 1711 körüli emlékirat tanulságai [Оценка положения дел и программа консолидации. К вопросу об одном меморандуме ок. 1711 г.] // Fons. - 2020. - No. 4. - S. 291-304. 
корпуса, где молодые дворяне воспитывались бы в истинно немецких нравах и направлялись бы на войну 9 .

По мнению автора, созданием такого корпуса, более активным привлечением молодых венгерских дворян к службе в действующей армии, открытием перед ними перспектив относительно быстрого получения офицерских чинов и карьерного роста правительство завоевало бы лояльность дворянства. Следующий пункт проекта предполагал создание рыцарской академии, что не только помогло бы «окультуриванию» дворянства, но и побудило бы его к несению полезных государю и отечеству служб ${ }^{10}$.

Сходные мысли звучали из уст советников, входивших в ближайшее окружение монарха, которые после освобождения Венгерского королевства от османского владычества и подавления Освободительной войны под предводительством Ракоци предлагали реализовать в королевстве модель военизированного дворянского общества. История Венгрии в XVII в. состояла из непрерывных военных конфликтов: одни были направлены против Османской империи, другие (при разной степени поддержки со стороны общества) - против господства Габсбургов. В XVIII в. соотношение сил склонилось в пользу двора, Карл VI (1711-1740) и особенно его дочь Мария Терезия (1740-1780) отвергали политику насильственной централизации и старались завоевать верность и поддержку дворянства более изощренными средствами. В контексте такой политики особую роль могла сыграть лейбгвардия, на создании которой настаивали ключевые фигуры в окружении монарха. В период консолидации, наступившей после подписания Сатмарского мира, один из виднейших венгерских политиков того времени - Калочайский епископ, кардинал, граф Имре Чаки (1672-1732) - всячески поддерживал идею создания при дворе гвардии, рекрутировавшейся из венгерских дворян, однако в правление Карла VI дело до этого так и не дошло ${ }^{11}$. В начале правления Марии Терезии, в первые годы войны за Австрийское наследство (1740-1748), военный и политический вес венгерских сословий в монархии Габсбургов существенно возрос. На коронационном государственном собрании в 1741 г. вместе с утопической идеей строительства в Буде королевской резиденции высказывалась идея создания венгерской лейб-гвардии ${ }^{12}$. В первой половине 1740-х гг. планы создания дворянской лейб-гвардии обсуждались

${ }^{9}$ CM.: MNL OL. - P 1901. I. s. d. - Nr. 13.

${ }^{10}$ Ibid.

11 Málnási Ö. Gróf Csáky Imre bíbornok élete és kora (1672-1732) [Жизнь и эпоха кардинала графа Имре Чаки]. - Kalocsa: Csáky család kiadása, 1933. - 148. old.

${ }^{12}$ Ballagi A. A magyar királyi testörség. - 28. old. 
неоднократно, об этом в труде «История и деяния Марии Терезии» ${ }^{13}$, посвященном первым годам ее правления, писал в том числе Кристиан Готтлоб Рихтер (1745-1791). Венгерская дворянская лейб-гвардия была учреждена спустя два десятка лет, в разгар Семилетней войны (1756-1763).

По поручению Марии Терезии венгерский надворный канцлер граф Миклош Палфи (1710-1773) 25 октября 1759 г. представил проект об учреждении лейб-гвардии ${ }^{14}$. По мнению канцлера, новый институт создавался для заботы об интересах и процветании Венгерского королевства: молодые дворяне в возрасте 18-20 лет попадали бы в Вену, оказывались в непосредственной близости от двора, усваивали тамошние обычаи и нравы, совершенствовались бы в дворянских упражнениях и науках, необходимых для будущей военной или статской карьеры. Уже тогда Палфи рассматривал лейбгвардию как своего рода школу, точнее образовательное учреждение, которое стало бы важным дополнением в ряду уже действовавших столичных дворянских академий. В то время в Вене их было три: Терезианум, Лёвенбурговский конвикт и Савойская академия, и во всех обучались дети венгерских магнатов и дворян, причем в первых двух венгерским воспитанникам предлагались стипендии ${ }^{15}$. Все три учебных заведения выполняли сложную функцию: их создали по примеру иностранных рыцарских

${ }^{13}$ Рихтер располагал сведениями о том, что планы учреждения венгерской лейб-гвардии обсуждались еще в 1744 г., они были вполне конкретны и находили поддержку у императрицы и ее советников, «но это не понравилось австрийскому дворянству», которое приложило все усилия к тому, чтобы помешать этому. См.: [Richter Ch.G.] Geschichte und Thaten der Allerdurchlauchtigsten und großmächtigsten Fürstin und Frau Maria Theresia jetztregierenden Königin in Hungarn und Boeheim... s. 1., 1745. - Vol. IV. - S. 45-46.

${ }^{14}$ Illéssy J. A magyar királyi nemes testőrség felállítása 1760 [Учреждение венгерской дворянской лейб-гвардии в 1760 г.] // Hadtörténelmi Közlemények. - 1895. - 8. évf. - 1. sz. 370-375. old. Выдержки из проекта приведены в двухтомной истории лейб-гвардии Иоганна Баптиста Скалля (1774-1832) - директора канцелярии Управления обер-шталмейстера (1813-1820). См.: Handschriftensammlung, Österreichische Nationalbibliothek. - Cod. Ser. No. 3919. - Skall J.B. Geschichte, Administrazion und Einrichtung der König. Ungar. Adel. Leibgarde. S. 22. В сочинении, оставшемся в рукописи, содержатся ссылки и пространные цитаты из источников, в том числе из документов, не сохранившихся до наших дней. Подробнее также см.: Mraz G. Johann Baptist Skall - Geschichte, Administration und Einrichtung der königlich ungarischen adeligen Leibgarde // Forscher - Gestalter - Vermittler. Festschrift Gerald Schlag / Hrsg. Von W. Gürtler. - Eisenstadt: Amt der BurgenländischenLandesregierung, 2001. - S. 239-252.

${ }^{15}$ На русском языке подробнее см.: Хаванова О.В. Заслуги отцов и таланты сыновей: венгерские дворяне в учебных заведениях монархии Габсбургов, 1746-1784. - СанктПетербург: Алетейя, 2006. О репрезентации Терезианума см.: Kökényesi Zs. Das Bild und die Repräsentation des Theresianums in der Öffentlichkeit des 18. Jahrhunderts // Wiener Geschichtsblätter. - 2015. - Jg. 70. - No. 3. - S. 263-280. 
академий для передачи юношеству новейших знаний и побуждения его к поступлению на государственную службу. Палфи полагал, что

[воспитанники] в этих академиях обучаются наукам, но не получают необходимого навыка поведения, у них нет никакой возможности сформировать представления о том, что ждет их во взрослой жизни, посему по возвращении домой то малое, что усвоили в академиях, из-за отсутствия практики быстро забывают, потом женятся и окончательно, бесповоротно теряют все, чем могли быть полезными для государя, Отечества и себя самих $^{16}$.

Иными словами, Палфи придавал лейб-гвардии исключительную роль в формировании менталитета, образа мыслей венгерского дворянства. Канцлер полагал, что с точки зрения карьерных возможностей, лейб-гвардия займет центральное место в подготовке кадров для венгерских полков, станет, так сказать, «школой офицерства» (“Pflanzschule der Offiziere”) 17 .

Изначально М. Палфи намеревался набирать лейб-гвардейцев из юношей 18-20 лет, но по совету оберст-гофмейстера графа Корфица Антона Ульфельда (1699-1769) повысил возраст зачисления до 20 лет $^{18}$. Канцлер считал крайне важным рекрутирование молодых дворян-протестантов, и в этом его поддержал Придворный военный совет. Однако, по настоянию Ульфельда, было принято решение, по которому доля протестантов в лейб-гвардии не должна была превышать одну треть личного состава ${ }^{19}$. Впоследствии, начиная с осени 1760 г., ведомство оберст-гофмейстера дважды в год издавало распоряжение, дозволявшее лейб-гвардейцам-протестантам посещать богослужение в расположенном неподалеку от Вены венгерском вольном королевском городе Шопроне ${ }^{20}$. В общем контексте политики рекатолизации рекрутирование в лейб-гвардию протестантов и разрешение им исповедовать свою религию было важным жестом габсбургского правительства.

Государственный канцлер, первейший советник Марии Терезии в вопросах внутренней и внешней политики, граф Венцель Антон Кауниц (1711-1794) счел необходимым изложить свое мнение об учреждении венгерской дворянской

${ }^{16}$ Skall J.B. Geschichte, Administrazion und Einrichtung der König. - S. 25-26.

${ }^{17}$ Skall J.B. Geschichte, Administrazion und Einrichtung der König. - S. 27. Об офицерских карьерах бывших гвардейцев см.: Khavanova O. Fascination with Uniform? Choosing between Military and Civil Careers in the Eighteenth-Century Habsburg Monarchy // Hungarian Studies. 2018. - Vol. 32. - No. 1. - P. 125-127.

${ }^{18}$ Skall J.B. Geschichte, Administrazion und Einrichtung der König. - S. $26,71$.

${ }^{19}$ Ibid. - S. 53, 72.

${ }^{20}$ Ibid. - S. 215. 
лейб-гвардии в записке от 16 апреля 1760 г. $^{21}$ В бытность послом в Париже в 1750-1753 гг. Кауниц уже предлагал учредить «дворянскую гвардию» ("gardenoble"), призванную обеспечить безопасность правящего дома, но в те годы до претворения проекта в жизнь дело не дошло. Государственный секретарь назвал новый институт полезным, ибо гвардия добавляла блеска двору и должна была оказать благотворное влияние на венгерское дворянство ${ }^{22}$. Кауниц счел нужным подчеркнуть, что расходы по ее содержанию должны нести венгерские комитаты (административно-территориальные единицы королевства $)^{23}$. Далее канцлер высказывал опасение, что у дворян АвстроЧешских наследственных провинций гвардия могла породить зависть, поскольку для их сыновей не предусматривалось подобного учреждения, а также потому, что гвардия повышала шансы на успешную карьеру лишь у венгерских дворян. Кауниц не исключал, что в будущем могли быть основаны новые гвардейские полки, пока же указывал на то, что в распоряжении молодых дворян из Наследственных провинций есть военные академии, дающие блестящее образование и открывающие прекрасные карьерные возможности, о чем не должны забывать их родители ${ }^{24}$. Он также отмечал

${ }^{21}$ Skall J.B. Geschichte, Administrazion und Einrichtung der König. - S. 86-97. Значение работы И.Б. Скалля тем выше, что записка В.А. Кауница не была известна ни венгерским, ни австрийским ученым, оригинал же в фондах Государственной канцелярии не сохранился. Согласно инвентарной описи, этот документ ранее хранился в фондах Австрийского государственного архива, см.: Österreichisches Staatsarchiv, Wien. Haus-, Hof- und Staatsarchiv. Staatskanzlei Vorträge. - Kt. 87. - Fol. 256 r.

${ }^{22}$ Skall J.B. Geschichte, Administrazion und Einrichtung der König. - S. 87-88.

${ }^{23}$ Ibid. - S. 88-89.

${ }^{24}$ Ibid. - S. 91. В тот период венгерское дворянство и в самом деле неохотно посещало созданную в 1717 г. в Вене Военно-инженерную академию или основанную в 1751 г. в Винер-Нойштадте Военную Терезианскую академию. См.: Kissné Bognár K. Magyarországi diákok a bécsi tanintézetekben, 1526-1789 [Студенты из Венгрии в венских учебных заведениях, 1526-1789]. - Budapest: Eötvös Loránd Tudományegyetem Levéltára, 2004. - 321334, 345-362. old. (Magyarországi diákok egyetemjárása az újkorban). После упразднения в 1755 г. фонда Каоса (основан в 1664 г. Иоганном Рихтхаузеном бароном Каосом), из которого финансировалось обучение сыновей и сирот австрийских, венгерских и хорватских дворян и офицеров, стипендиаты из Венгерского королевства продолжили учебу в венской Инженерной академии. См.: Khavanova O. Eine universitäre Lehrveranstaltung als universales Instrument: Joseph von Sonnenfels und die administrative Elite der Habsburgermonarchie // Die Anatomie frühneuzeitlicher Imperien. Herrschaftsmanagement jenseits von Staat und Nation / Hrsg. von S. Wendehorst. - Berlin; München; Boston: Walter de Gruyter, 2015. - S. 106. Подробнее об обучении венгерского дворянства в Вене, в том числе подсчеты числа венгерских дворян в Терезиануме, см.: Khavanova $O$. Der ungarische Adel am Wiener Theresianum im 18. Jahrhundert: die sozialen und kulturellen Grenzen einer politischen Nation // Österreichisch-ungarische Beziehungen auf dem Gebiet des Hochschulwesens = Osztrák-magyar felsőoktatási kapcsolatok / Szerk. Zs.K. Lengyel, J.Zs. Nagy, G. Ujváry. - Székesfehérvár: 
своевременность учреждения лейб-гвардии с точки зрения комплектации армии и улучшения подготовки офицерского корпуса Габсбургской монархии в разгар войны с Пруссией.

Подготовительный период занял около года, когда были решены вопросы финансирования, правового статуса, рекрутирования гвардейцев, строительства дворца, закупки лошадей, униформы и пр. Профиль и правовой статус лейбгвардии был определен в привилегии, изданной 11 сентября 1760 г., по которой лейб-гвардия являлась полноправным военным и придворным институтом, штат устанавливался в 120 человек, набиравшихся в трансильванских, хорватских и венгерских комитатах ${ }^{25}$. Упоминание о трансильванских дворянах не было делом само собой разумеющимся, поскольку Венгерское королевство и Трансильванское княжество в то время считались особыми государственными образованиями, но канцлер Габор Бетлен (1712-1768) и губернатор Ласло Кемень сделали все возможное, чтобы лейб-гвардейцами могли стать представители трех политических «наций», проживавших на территории Трансильвании (венгры, саксы и секлеры) ${ }^{26}$. Учреждение венгерской дворянской лейб-гвардии сопровождалось пышными многолюдными торжествами 27-28 сентября 1760 г. в административной столице королевства Пресбурге (совр. Братислава, Словакия) ${ }^{27}$. Событие привлекло к себе внимание общественности, а в приложении к официальной придворной газете “Wienerisches Diarium” («Венский дневник») была опубликована подробная программа мероприятия, причем лейб-гвардия именовалась не иначе, как

начинание, которое послужит исключительно почету, украшению и пользе достославной венгерской нации ${ }^{28}$.

Эффектный венский дебют лейб-гвардии состоялся неделю спустя, 6 октября 1760 г., в ходе долгожданных, пышно отпразднованных торжеств по случаю бракосочетания эрцгерцога Иосифа и Изабеллы Пармской ${ }^{29}$.

Kodolányi János Főiskola; Budapest: Eötvös Loránd Tudományegyetem Könyvtára, 2010. - 107122. old. Подробнее о военных академиях см.: Shek Brnardić T. The Enlightened Officer at Work: The Educational Projects of the Bohemian Count Franz Joseph Kinsky (1739-1805): PhD thesis. - Central European University, 2004. (рукопись)

${ }^{25}$ Hadtörténeti Levéltár, Budapest [Военно-исторический архив, Будапешт; далеe - HL]. A királyi magyar nemesi testőrség iratai [Бумаги венгерской дворянской лейб-гвардии], 1760. Kt. 1. - Nr. 3. Впоследствии численность лейб-гвардии сократили в 1769 г. до 90, в 1770 г. до 80, в 1778 г. - до 60 человек.

${ }^{26}$ Skall J.B. Geschichte, Administrazion und Einrichtung der König. - S. 17-18; MNL OL. Erdélyi Kancellária. B 2. 1760. - No. 342.

${ }^{27}$ Skall J.B. Geschichte, Administrazion und Einrichtung der König. - S. 194-207.

${ }^{28}$ Wienerisches Diarium. - 1760. - 04 X. 


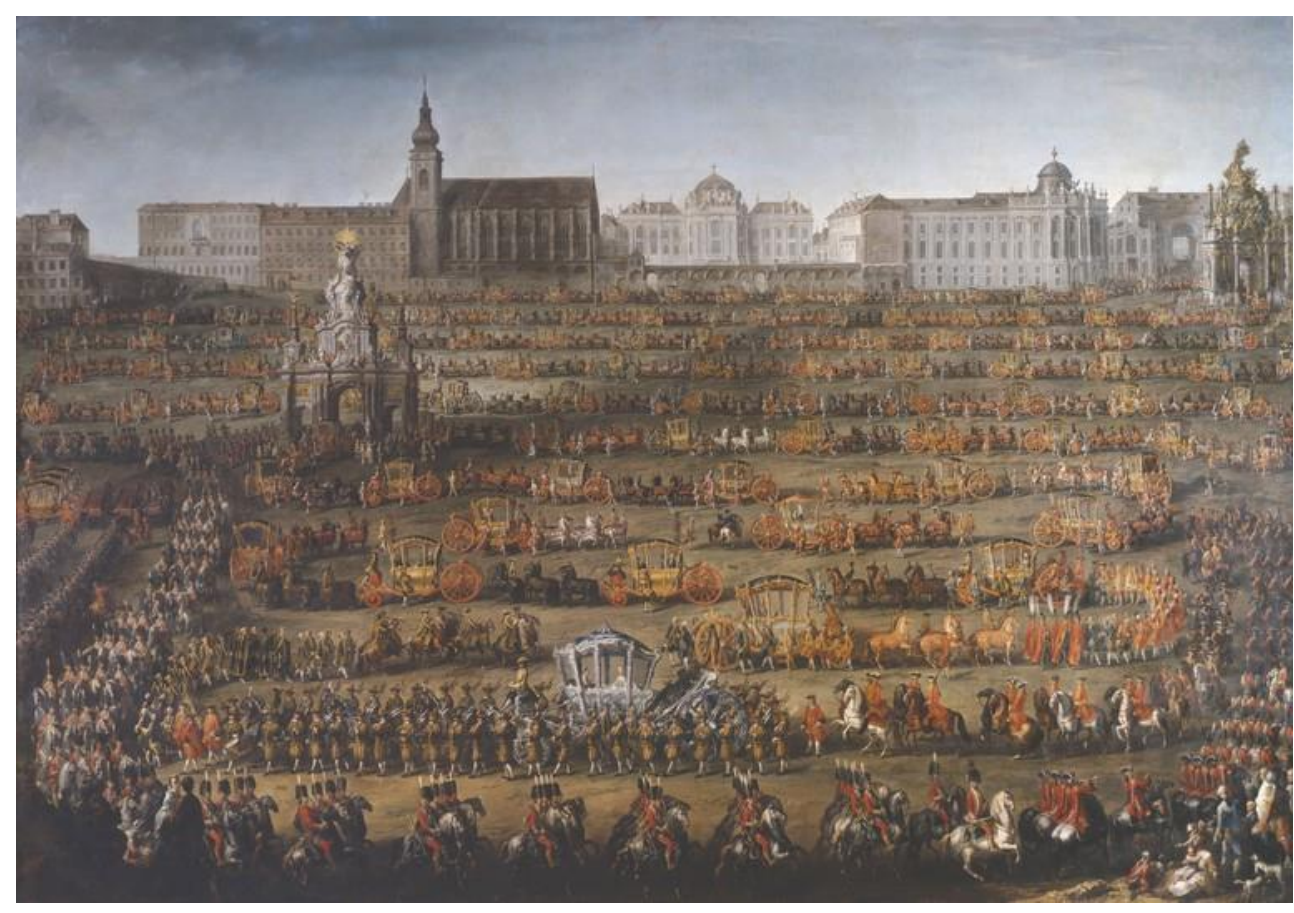

М. Мейтенс. Торжественный въезд Изабеллы Пармской в Вену. Среди участников процессии - венгерские лейб-гвардейцы.

Источник: URL: https://upload.wikimedia.org/wikipedia/commons/2/25/ Martin_van_Meytens_012.jpg

\section{Прямое и опосредованное приобщение к культуре}

Будни лейб-гвардейцев, с одной стороны, состояли в несении дворцовой караульной службы, где они обеспечивали охрану и пышный эскорт членам правящего дома в столице и на выезде. С другой стороны, лейб-гвардия открывала для молодых венгерских дворян возможности прямого и опосредованного приобщения к культуре. В число официально вмененных лейб-гвардейцам обязанностей входило

в часы, свободные от несения службы, совершенствоваться в языках, на которых говорят при императорско-королевском дворе, и важных и полезных науках ${ }^{30}$.

Молодым дворянам полагалось изучать немецкий и французский языки, практиковаться в «дворянских упражнениях» (танцы, фехтование, верховая езда), большое значение придавалось изучению военной инженерии. Лейб-

${ }^{29}$ Báróczy Sándor feljegyzései a Magyar Nemesi Testőrség életéből 1760-1800-ig [Записки Шандора Бароци о жизни в венгерской дворянской лейб-гвардии с 1760 по 1800 г.] / Összeállította F. Krudy; fordította J.K. László. - Budapest: M. Kir. Hadilevéltár, 1936. - 17. old.

${ }^{30}$ HL. A királyi magyar nemesi testőrség iratai. 1760. - Kt. 1. - Nr. 5. 
гвардия также позволяла факультативно изучать ${ }^{31}$ английский и итальянский языки, юриспруденцию и политико-камеральные науки ${ }^{32}$. Таким образом, лейбгвардия, в соответствии с первоначальным замыслом, превратилась в культурно-просветительский институт, позволявший изучать предметы, которые не преподавались в то время в иезуитских гимназиях, но могли впоследствии пригодиться как на статской, так и на военной службе. Сходное образование давали в зарубежных (французских, немецких, итальянских) рыцарских академиях, а характерное сочетание образовательной программы с дворянским воспитанием наблюдалось уже в первых дворянских гвардиях. При дворе Августа II Сильного гвардейская служба дополнялась программой подготовки офицеров, для кадетов нанимали учителей фехтования, иностранных языков и танцев, преподавали им географию, математику, историю, этику, начала архитектуры ${ }^{33}$. Габсбурги, состоявшие в родстве с Веттинской династией, при учреждении дворянской лейб-гвардии могли взять это за образец. Изо всех гвардий при венском дворе желание дополнить службу воспитательно-образовательной программой было характерно не только для венгерского полка, но и для созданной в 1782 г. галицийской гвардии ${ }^{34}$. В ней за пять лет придворной службы шляхтичи также осваивали грамотно составленный курс наук, включавший иностранные языки, математику, философию, юриспруденцию, науки о государстве.

Для молодых дворян годы службы в лейб-гвардии означали не только обучение в прямом смысле слова, но и приобщение к возможностям культурного развития и обзаведения полезными связями, которые открывала Вена. Регулярное посещение театра считалось обязательным, а некоторым высокообразованным и располагавшим широким кругом знакомств молодым людям удавалось проникать даже в масонские ложи. В списках многих лож можно встретить по одному-два имени венгерских лейб-гвардейцев, особенно в первой половине 1780-х гг. (период расцвета венского масонского движения) $)^{35}$. Например, Имре Берзевици (1745-1796) состоял в ложе “Zu den drei Adlern” («K трем орлам»), Балинт Бачкади (1750-1815) - в “Zurgekrönten Hoffnung” («K

${ }^{31}$ A magyar testőrségek névkönyve. - 47-48. old.

32 Политико-камеральные науки - учебная дисциплина во второй половине XVIII в., в рамках которой давались базовые знания о государстве, обществе, экономике и финансах.

${ }^{33}$ Moser C.F. Teutsches Hof-Recht. - S. 238.

34 Gestrich A. Die galizischen adeligen Leibgarden am Wiener Hof. Ein Beispiel habsburgischer Inklusionspolitik nach den Teilungen Polen-Litauens // Militär und Gesellschaft in der Frühen Neuzeit. - 2013. - Jg. 17. - No. 1. - S. 41-64.

${ }^{35}$ Rosenstrauch-Königsberg E. Freimaurerei im josephinischen Wien. Aloys Blumauers Weg vom Jesuiten zum Jakobiner. - Wien; Stuttgart: W. Braumüller, 1975 (Wiener Arbeiten zur deutschen Literatur. Bd. 6). 
коронованной надежде»), как и Йожеф Кузмич (1741-?), который не прекратил членства в ложе, даже вернувшись после выхода в отставку в родной Дебрецен, где получил должность советника ${ }^{36}$. С точки зрения масонских связей не менее важно, что многие лейб-гвардейцы посещали заседания такого интеллектуального центра Вены, как ложа Игнаца фон Борна (1742-1791) “Zurwahren Eintracht” («К истинной гармонии»). В их числе были и будущий письмоводитель Трансильванской придворной канцелярии Йожеф Данцкаи (1752-?) и сделавший блестящую офицерскую карьеру Йожеф Доци (1741$1825)^{37}$.

Для провинциальных дворян Вена с ее 200-тысячным населением была своеобразным окном в Европу и столичную культуру. В качестве лейбгвардейцев молодые люди бывали не только в Вене и Пресбурге, но и в Милане, где в 1771-1778 гг. при губернаторе Ломбардии эрцгерцоге Фердинанде находился отряд из 26 венгерских лейб-гвардейцев ${ }^{38}$ В 1778 г. Иосиф II распорядился привлекать к исполнению обязанностей курьеров наиболее смышленых лейб-гвардейцев, что не только повышало их статус, но и расширяло географические познания и общий кругозор. Вендел Бачак (17571840), уроженец комитата Пресбург, в качестве гвардейца-курьера побывал в Бельгии, Италии, Франции, Польше и России. О поездке в Италию в 1784 г. он записал следующее:

[Леопольд, великий герцог Тосканский,] был со мной исключительно любезен; узнав, что я не видел моря, отправил меня в свой средиземноморский город-порт Ливорно. Здесь впервые я увидел море, попробовал на вкус морскую воду, она оказалась горьковато-соленой ${ }^{39}$.

На следующий год Бачак вновь посетил Северную Италию:

Император отправил меня в Милан, чтобы я повидал и этот город, распорядился, чтобы товарищ мой Бачкади ${ }^{40}$, который прибыл туда ранее,

36 Österreichisches Staatsarchiv, Wien. Haus-, Hof- und Staatsarchiv. Kabinetsarchiv. Vertrauliche Akten. - Kt. 72. - Konv. 7. - Fol. 144, 246-247.

37 Irmen H.J. Die Protokolleder Wiener Freimaurerloge „Zur Wahren Eintracht” (17811785). - Wien: Peter Lang, 1994. - S. 348 (Schriftenreihe der Internationalen Forschungsstelle Demokratische Bewegungen in Mitteleuropa 1770-1850. Bd. 15).

${ }^{38}$ A magyar testörségek névkönyve. - 14. old.

${ }^{39}$ Nyakas S. Benefai Batsák Vendel utazásai [Путешествие Вендела Бенефаи-Бачака] // Közlemények a pécsi Erzsébet Tudományegyetem Könyvtárából. - 1932. - 14. sz. - 1-8. old.

${ }^{40}$ Речь идет об упомянутом выше лейб-гвардейце Балинте Бачкади. 
показал мне все достопримечательности (нет слов, чтобы описать, сколь милостиво относился император к венгерской гвардии $)^{41}$.

Эти и подобные поездки помогали молодым людям набраться опыта и получить новые впечатления.

Картина не будет полной, если не отметить, что свобода маневра и возможность удовлетворения молодыми лейб-гвардейцами интеллектуальных запросов в значительной мере зависели от текущего момента в политике габсбургского правительства, от суровости цензуры. Например, в 1767 г. Мария Терезия через ведомство оберст-гофмейстера издала декрет о запрете на вольнодумство (Freigeisterei) и идеи, прямо противоречащие католическому вероучению, которые в то время получили хождение при дворе и среди лейбгвардейцев ${ }^{42}$. Владельцам книг с подобным содержанием давалось восемь дней, чтобы их сжечь, в противном случае нарушителей ждали отставка и наказание. Или, например, после издания Иосифом II масонского патента (1785 г.) вступление в ложи было затруднено.

Лейб-гвардия являлась не только придворным или образовательным институтом, но и военной организацией, требовавшей от гвардейцев серьезной дисциплины и порядка. Многим выполнение подобных требований давалось с трудом или не удавалось совсем. В архиве венгерской лейб-гвардии хранятся «Протоколы дисциплинарных взысканий» (Straffprotokolle), в которых детально зафиксированы нарушения, долги и мелкие проступки охочих до развлечений в имперской столице лейб-гвардейцев. Например, Пал Будаи (1748-?) 2 февраля 1771 г. вернулся в казарму после закрытия ворот, нагрубил караульному и на 24 часа был отправлен на гауптвахту ${ }^{43}$. Похожее наказание получил Антал Томчани (1746-1793), впоследствии определенный к миланскому гвардейскому полку: его застали в комнате за курением и поеданием мяса (разрешенного в тот день недели только больным $)^{44}$. Случались и более серьезные нарушения: карточные долги (игра была под запретом!) и нередкие потасовки.

\footnotetext{
${ }^{41}$ Nyakas S. Benefai Batsák Vendel. - 4. old.

${ }^{42}$ HL. A királyi magyar nemesi testőrség iratai. - 8/4.

${ }^{43}$ HL. A királyi magyar nemesi testőrség iratai. - 8/4. - Bd. 200. - Fol. 1r.

${ }^{44}$ Ibid. - Fol. 1v.
} 


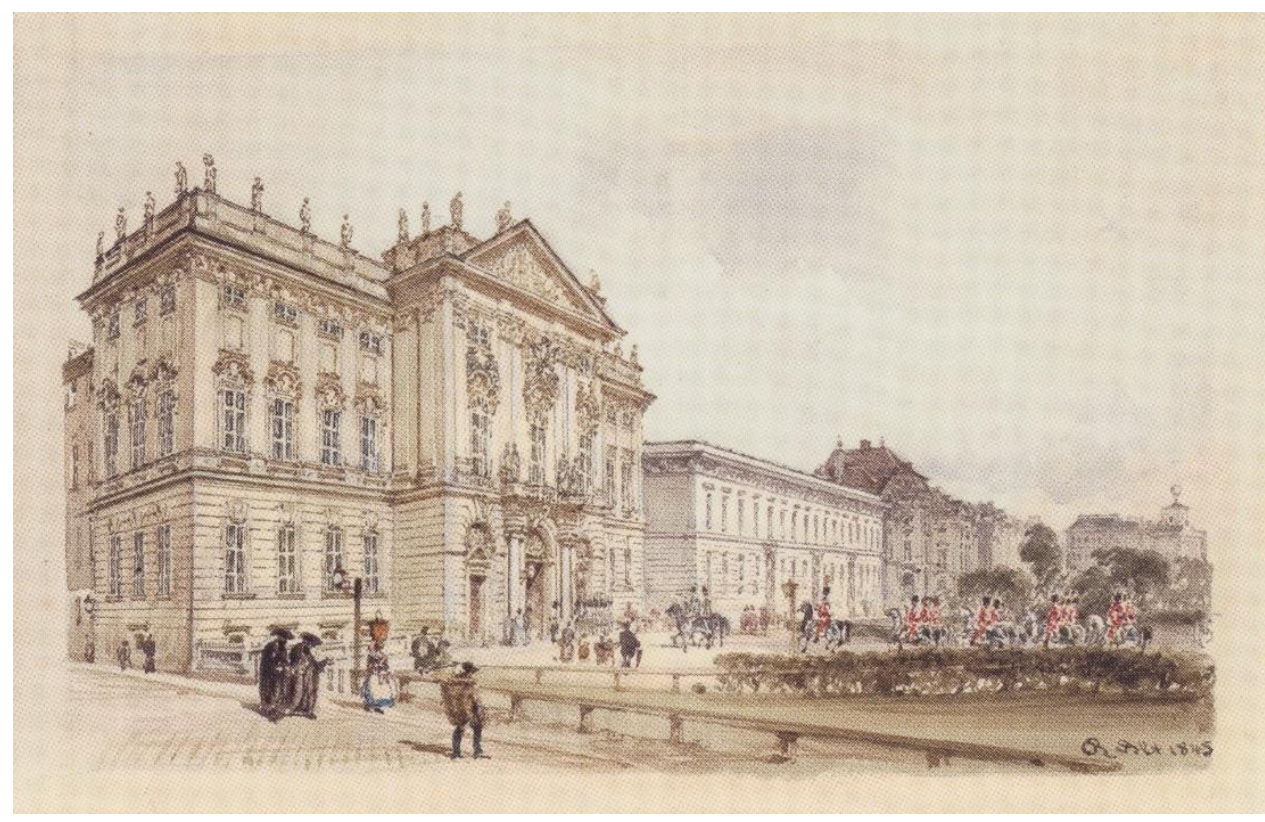

Р. фон Альт. Дворец Траутсонов (1845 г.).

В 1760-1848 гг. служил резиденцией венгерской дворянской лейб-гвардии.

Источник: URL: https://upload.wikimedia.org/wikipedia/commons/5/59/Rudolf_von_Alt__Das_Palais_Trautson_in_Wien_-_1845.jpeg

\section{Место лейб-гвардии в карьерах венгерских дворян}

Венгерская дворянская лейб-гвардия объединяла молодых людей из разных частей королевства, несхожих по происхождению, социальному статусу и мировоззрению: в полку служили выходцы из Трансильвании, Хорватии и Венгрии, среди них были как католики, так и протестанты. Большинство лейбгвардейцев происходило из дворян средней руки, реже встречались мелкие дворяне и аристократы. Ниже рассматривается несколько примеров типичных карьер с преимущественным вниманием к периоду учебы и начала службы.

В отношении аристократов в лейб-гвардии необходимо подчеркнуть, что они могли исполнять обязанности не только гвардейских офицеров, но и рядовых гвардейцев. Еще в проекте 1759 г. канцлер Миклош Палфи предполагал зачисление в лейб-гвардию магнатских сыновей. Верхушку господствующего класса Венгерского королевства составляли крупные землевладельцы Западной Венгрии, семьи, обязанные своим возвышением Габсбургам: Эрдёди, Эстерхази, Палфи. Их представители встречались как в рядах гвардейских офицеров, так и среди командования; из боковых линий таких семей рекрутировались и рядовые гвардейцы, особенно в первые годы существования института. Одним из богатейших и влиятельнейших семейств Венгрии были Баттяни: на момент учреждения лейб-гвардии высшую должность королевства, пост надора (королевского наместника) занимал граф Лайош Баттяни (1696-1765), его младший брат Карой (1697-1772) служил 
оберст-гофмейстером эрцгерцога Иосифа и конференц-министром при венском дворе. Двоюродный брат Лайоша и Кароя - Имре Эрнё Баттяни (1701-1774) был судьей Септемвирального суда и обер-мундшенком ${ }^{45}$. Его отец, граф Жигмонд Баттяни (?-1728), дал сыну блестящее домашнее образование, затем на три года отправил в иезуитскую гимназию в расположенный неподалеку от родовых владений Кёсег, далее юноша изучал риторику и философию в Граце, юриспруденцию - в бенедиктинском университете в Зальцбурге ${ }^{46}$. Своим сыновьям Имре Баттяни тоже хотел дать блестящее образование, но материальные возможности были ограничены, речь о посещении зарубежных университетов или гранд-туре не шла. Он предпочел дать детям домашнее образование, а затем отправить их в одну из венских рыцарских академий. Стипендии, учрежденные в Вене для венгерских дворян, были весьма кстати, и Баттяни сумел получить их на двоих из четырех своих сыновей. Йожеф (17371806) - будущий вице-президент Венгерской казенной палаты, Игнац (17411798) - будущий Трансильванский епископ, обучались в Терезиануме как платные воспитанники, Антал (1747-1814) - как стипендиат ${ }^{47}$. Имре Баттянимладший (1744-1819) учился в гимназии в Граце, добыть для него стипендиальное место в Терезиануме отец не смог, пришлось довольствоваться более скромным Лёвенбурговским конвиктом. По окончании курса наук Имре был зачислен в дворянскую лейб-гвардию, где прослужил чуть более двух лет. В дальнейшем он выбрал карьеру военного, но не дослужился до высокого ранга.

Более удачно сложилась военная карьера у барона Имре Реваи (1751-1791), который был произведен в подполковники и награжден рыцарским крестом

${ }^{45}$ Wißgrill F.K. Schauplatz des landsässigen Nieder-Oesterreichischen Adels vom Herren- und Ritterstande von dem XI. Jahrhundert an, bis auf jetzige Zeiten. - Wien: Gedrucktbey F. Seizer, 1794. - Vol. I. - S. 315.

${ }^{46}$ И.Э. Баттяни с 1717 по 1719 г. обучался в классе грамматики и поэтики Кёсегской гимназии. См.: Magyar Nemzeti Levétár Vasmegyei Levéltára, Sopron [Архив комитата Ваш Венгерского национального архива, Шопрон; далее - MNLVaML]. Köszegi Fióklevéltár [Кёсегский филиал; далее - KFL]. - VIII. - 52. - Fol. 86 r - 93 r. Varga J. Magyarországi diákok a Habsburg Birodalom kisebb egyetemein és akadémiáin 1560-1789 [Студенты из Венгрии в малых университетах и академиях Габсбургской империи]. - Budapest: Eötvös Loránd Tudományegyetem Levéltára, 2004.

${ }^{47}$ См.: Kissné Bognár K. Magyarországi diákok. - 337-339. old. В пропозиции Венгерской придворной канцелярии имена братьев Баттяни не указаны, но об Антале известно, что он учился в Терезиануме. См.: MNL OL. Magyar kancelláriai levéltár. A Magyar Királyi Kancellária regisztratúrája Originales referadae. [Архив Венгерской канцелярии. Регистратура Венгерской придворной канцелярии. Оригиналы актов]. - A 1. - 1762. - Nr. 202. 
Ордена Марии Терезии ${ }^{48}$. Он происходил из древнего, разветвленного, но в иерархии стоявшего позади многих магнатских семейств рода, его отец Мозеш владел скромными поместьями в расположенном далеко от Вены комитате Туроц и в Сепешском крае ${ }^{49}$. В 1761-1767 гг. Имре получил блестящее образование в иезуитской гимназии в Надьсомбате (совр. Трнава, Словакия), там же он был королевским стипендиатом в дворянском конвикте ${ }^{50}$. По окончании гимназии Имре Реваи недолгое время обучался в Терезианской военной академии в Винер-Нойштадте, затем поступил в пехотный полк Пуэблы ${ }^{51}$. Три года он отдал службе в лейб-гвардии, где был прикомандирован к миланскому отряду.

С точки зрения полезных знакомств и интеграции в придворное общество дворянская лейб-гвардия была особенно привлекательна для дворян и аристократов из восточной Венгрии и Трансильвании. Не будь лейб-гвардии, молодой протестант из Трансильвании барон Йожеф Налаци (1748-1822) никогда бы не смог провести в габсбургской столице два года и в полной мере использовать возможности для повышения своего культурного уровня ${ }^{52}$. Юноша рано лишился отца, учебу окончил в реформатском коллегиуме в Надьеньеде (совр. Аюд, Румыния), до зачисления в лейб-гвардию успел потрудиться нотарием (мелким клерком) в трансильванской королевской судебной палате. Решающую роль в том, что барон-протестант из Трансильвании попал в Вену, сыграла рекомендация губернатора, графа Андраша Хадика (1710-1790), который в письме к капитану лейб-гвардии князю Миклошу Эстерхази (1714-1790) отдал должное исключительным способностям юноши и политической лояльности его семьи ${ }^{53}$. Налаци

${ }^{48}$ Hirtenfeld J. Der Militär-Maria-Theresien-Orden und seine Mitglieder. - Wien: K-K. Hof und Staatsdruckerei, 1857. - S. 305.

${ }^{49}$ Fónagy Z. A nemesi birtokviszonyok az úrbérrendezés korában [Поместное землевладение в период проведения урбариальной реформы]. - Budapest: Magyar Tudományos Akadémia Bölcsészettudományi Központ Történettudományi Intézete, 2013. - 1320. old.

${ }^{50}$ MNL OL. Magyar kancelláriai levéltár. A Magyar Királyi Kancellária regisztrátúrája Originalesreferadae [Архив Венгерской канцелярии. Регистратура Венгерской королевской канцелярии. Оригиналы актов]. А 1. - 1762. - Nr. 217; Nagyszombati adattár. A nagyszombati jezsuita gimnázium diáksága. Anyakönyvi adattár (1616-1772) [Надьсомбатская база данных. Студенчество Надьсомбатской иезуитской гимназии. Матрикулярная база данных (16161772)]. - Nr. 30160. - URL: https://library.hungaricana.hu/hu/view/JezsuitaGimnaziumok Diakjai_2_Nagyszombat/?pg=0\&layout=s (дата обращения: 24.07.2020).

51 A magyar testörségek névkönyve. -317 . old.

52 Ibid. - 270. old.

${ }^{53}$ MNL OL. Családi fondok, levéltárak [Семейные фонды и архивы]. Családi levéltárak [Семейные архивы]. Esterházy család hercegi ága [Княжеская ветвь рода Эстерхази]. Repertóriumok [Реперториумы]. - P. 108. - Rep. 98. - Fasc. M. - № 17. 
пришлась по душе служба в лейб-гвардии, он провел в Вене долгие семь лет. Накопленный опыт пригодился впоследствии как на военной, так и на статской службе. Вершиной его карьеры стала должность фёишпана (губернатора) комитата Заранд, полученная в 1792 г. ${ }^{54}$ Налаци вошел в историю не только как государственный деятель, но и как ключевая фигура трансильванской реформатской общины, а также автор ряда литературных произведений и переводов.

Для особо одаренных и удачливых дворян лейб-гвардия становилась средством улучшения социального положения, как это произошло, например, в случае с Анаталом Литаи (1745-1800) - среднепоместным дворянином из комитата Ноград 55 . Учеба и служба сложились для него крайне удачно: он окончил гимназию в центре католического образования Венгрии - в Трнаве, затем в течение двух лет посещал класс риторики в Пресбурге ${ }^{56}$. В семье полагали, что юноша изберет духовную стезю. Однако католическими священниками стали два его брата, Адальберт и Пал, Антал же выбрал светскую карьеру $^{57}$. В 1763-1764 гг. он служил мелким клерком в Королевском наместническом совете, затем по рекомендации комитата Пресбург был зачислен в лейб-гвардию ${ }^{58}$. После четырех лет в Вене он не вернулся за конторку, а продолжил службу в армии, где в 1788 г. удостоился рыцарского креста Ордена Марии Терезии, получил ранг барона и к 1799 г. дослужился до генерал-лейтенанта ${ }^{59}$. В свободное от воинской службы время Липтаи был активным масоном, сначала - членом ложи “Zur Wachtsamkeit” («К бдительности»), а в 1786 г. был назначен заместителем великого магистра пештской ложи “Zur Grossmuth” («K великодушию») ${ }^{60}$. В 1780-е годы он начал

${ }^{54}$ A magyar testőrségek névkönyve. - 270. old.

55 Skall J.B. Geschichte, Administrazion und Einrichtung der König. - 238. old.

56 Nagyszombati adattár. - № 29271; Pozsonyi adattár A pozsonyi jezsuita gimnázium diáksága. Anyakönyvi adattár (1650-1773) [Пресбургская база данных. Студенчество Пресбургской иезуитской гимназии. Матрикулярная база данных (1650-1773)]. № 17507. URL: https://library.hungaricana.hu/hu/view/JezsuitaGimnaziumokDiakjai_3_Pozsony/?pg= 0\&layout=s (дата обращения: 24.07.2020).

${ }^{57}$ Nagy I. Magyarország családai. Czímerekkel és nemzékrendi táblákkal [Семьи Венгрии. С гербами и генеалогическими таблицами]. - Pest: Ráth Mór, 1860. - VII. köt. - 132. old.

58 Ember Gy. A m. kir. Helytartótanács ügyintézésének története 1724-1848 [История делопроизводства в Венгерском королевском наместническом совете, 1724-1848 гг.]. Budapest: M. Kir. Országos Levéltár, 1940. - 233. old.

${ }^{59}$ Hirtenfeld J. Der Militär-Maria-Theresien-Orden. - S. 243-244.

${ }^{60}$ Abafi L. A szabadkőmüvesség története Magyarországon [История масонства в Венгрии]. - Reprint. - Győr: Tarandus Kiadó, 2012. - 277. old.; Kökényesi Zs. Egyháziak, katonák, nemesek. Eszéki, károlyvárosi és selmecbányai szabadkőmúves páholyok tagjai 1785-ben 
издавать сводки боевых действий и географические карты, но не преуспел в этом.

Большинство лейб-гвардейцев рекрутировались, естественно, не из магнатов и впоследствии им не удалось стать ни баронами, ни графами. Гораздо более типичной представляется карьера Пала Рошти (1745-1810). Его зажиточное семейство происходило из комитата Ваш в Западной Венгрии, где на протяжении многих поколений активно участвовало в политической жизни на местном и общегосударственном уровнях ${ }^{61}$. Отец Пала - Ференц Рошти (1718-1790) - был членом комитатского самоуправления и представлял комитат на Государственном собрании нескольких созывов ${ }^{62}$. Пал посещал иезуитскую гимназию в соседнем Кёсеге, затем обучался в Шопроне ${ }^{63}$. Вскоре комитат Ваш рекомендовал его к зачислению в венгерскую дворянскую лейбгвардию, где юноша прослужил пять лет ${ }^{64}$. Он выбрал карьеру военного, но в 1795 г. ее оборвало участие в заговоре так называемых венгерских якобинцев во главе с Игнацем Мартиновичем. Рошти провел год в тюрьме, а после вернулся в родной комитат, где получил должность судьи ${ }^{65}$.

\section{Заключение}

Самыми знаменитыми офицерами венгерской дворянской лейб-гвардии считаются Дёрдь Бешшенеи (1747-1811) и Абрахам Барчаи (1742-1806), без которых было бы немыслимо венгерское литературное Просвещение ${ }^{66}$. Но значение лейб-гвардии как социального института не сводится к этим двум именам. В соответствии с первоначальным замыслом, лейб-гвардия многим и

[Церкви, солдаты, дворяне. Члены масонских лож Эсека (Осиека), Каройвароша (Карловаца) и Шелмецбани (Банска-Штъявницы) в 1785 г.] // Polymatheia. - 2020. - 3-4. sz. - 53-85. old.

${ }^{61}$ Fónagy Z. A nemesi birtokviszonyok. - 1326. old.

${ }^{62}$ Bezerédj I. Rosti Ferenc levelei az 1764-65. évi pozsonyi országgyülésből [Письма Ференца Рошти с Государственного собрания 1764-1765 гг. в Пресбурге] // Dunántúli Szemle. - 1943. - 10. évf., 1-2. sz. - 4-20. old.

${ }^{63}$ В 1756 г. он окончил начальную школу (principista) в Кёсеге, в 1757 г. - обучался в классе грамматики (grammatista). См.: MNL VaML. KFL VIII. 52. - Fol. 217 r - 220 v. B Шопроне в 1758-1760 гг. - окончил классы синтаксиса, поэтики и риторики (syntaxis, poetica és rhetorica). См.: MNL Győr - Moson - Sopron Megye Soproni Levéltára. VIII. 52 (пагинация отсутствует).

${ }^{64}$ A magyar testőrségek névkönyve. - 320. old.

65 Benda K. A magyar jakobinusok iratai [Бумаги венгерских якобинцев]. - Budapest: Akadémiai kiadó, 1952. - 2. köt. - 682. old.

${ }^{66}$ Szilágyi M. Ein ungarischer Schriftsteller im theresianischen Wien: Georg Bessenyei // Wiener Archivforschungen. Festschrift für den Ungarischen Archivdelegierten in Wien, István Fazekas / Hrsg. Zs. Cziráki, et al. - Wien: Institut für ungarische Geschichtsforschung in Wien, 2014. - S. 287-294. 
многим дворянам открыла возможность повысить культурный уровень, позволила реализовать мечту о гранд-туре или обучении за границей. По сравнению с ограниченным кругом магнатов и дворян, которым удавалось попасть в венские рыцарские академии, лейб-гвардия распахнула двери для десятков венгров из отдаленных уголков королевства. В годы правления Марии Терезии их число вместе с гвардейскими офицерами равнялось примерно четыремстам, что в четыре раза больше, чем число венгерских, хорватских и трансильванских дворян в Терезиануме за тот же период (с 1760 по 1780 г.) ${ }^{67}$. Лейб-гвардии досталась решающая роль в выстраивании более тесных контактов между габсбургской столицей и венгерскими комитатами, а также в процессе ознакомления молодых венгров с западно- и центральноевропейской культурой. Еще больше интеллектуальных импульсов получали те, кому довелось служить за границей или выполнять функции курьеров. Возвращаясь к семьям и в родные комитаты, они делились впечатлениями с провинциальным венгерским обществом.

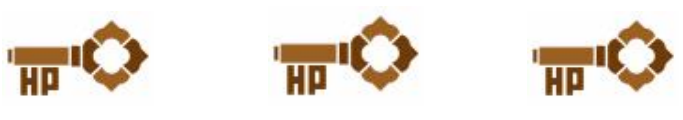

67 Kissné Bognár K. Magyarországi diákok. - 335-345. old.; A magyar testőrségek névkönyve. - 61-404. old. 
In the old days, the princely guards were far from as numerous as they are today; in extreme cases, the sovereign had at his disposal his own detachments of different nature and different quality established for this purpose. ${ }^{1}$

These lines, written in the middle of the $18^{\text {th }}$ century, belong to the famous German lawyer and political writer Friedrich Karl von Moser (1723-98). The establishment of the Royal Hungarian Bodyguard in 1760 fits into the picture he described perfectly well. At that time, the number and staff of the guards at major European courts increased markedly, and the Viennese court was no exception. While in the $16^{\text {th }}-17^{\text {th }}$ centuries there were only two guards ("Hartschiere" and "Trabanten") numbering about 100 people in the imperial capital, in the second third of the $18^{\text {th }}$ century there were years when six guard formations with total personnel of 400-500 people served as guardsmen simultaneously. ${ }^{2}$

The main distinguishing feature of the Royal Hungarian Bodyguard, as the name implies, was its "Hungarian" and "noble" nature. At the Viennese court, it was the only one formed according to the territorial principle. This made it similar to the Swiss Guards the formations of which started to be established everywhere in Europe in the $16^{\text {th }}-17^{\text {th }}$ centuries. ${ }^{3}$ The appearance of the noble guards can be referred to as one of the features of the European court culture of the $18^{\text {th }}$ century: almost simultaneously, similar formations were established by Elector Augustus II the Strong in Dresden, Duke Ernest Augustus in Weimar and Duke Eberhard Ludwig of Württemberg. ${ }^{4}$ The creation of the noble guards equally responded the interests of the sovereign princes and estates. On the one hand, carrying out the duties of a guardsman was qualified as military service, which perfectly fitted into the traditional ethos of the noble class and corresponded to its ideas about the vocation; on the other hand, this institution helped young noblemen to acquire connections and get a position at the court in the future. For the ruler, the establishment of the guards

${ }^{1}$ F.C. von Moser, Teutsches Hof-Recht, zwölf Büchern, Buch 1 (Frankfurt; Leipzig: Johann Benjamin Andrea, 1754), 224.

${ }^{2}$ For the functions and operation principles of the guards, see I. Cerman, Habsburgischer Adel und Aufklärung. Bildungsverhalten des Wiener Hofadels im 18. Jahrhundert, Contubernium. Tübinger Beiträge zur Universitäts- und Wissenschafts geschichte, Bd. 72 (Stuttgart: Franz Steiner Verlag, 2010), 133-36; G. Rakuscha, Die Leibgarden am österreichischen Herrscherhof (PhD diss., University of Vienna, 1981); R.M. Urrisk-Obertyński, Die k. u. k. Leibgarden am österreichischungarischen Hof 1518-1918 (Gnas: Weishaupt, 2004), 43-258.

${ }^{3}$ In 1699, the guard staffed by soldiers from the Swiss canton of Lucerne was established at the court of the Duke of Lorraine. In 1737, when Duke Francis exchanged Lorraine for Tuscany, they followed him to Florence, and after his coronation as Holy Roman Emperor in Frankfurt am Main in 1745, they moved to Vienna. See R.M. Urrisk-Obertyński, Die k. u. k. Leibgarden, 53-56.

${ }^{4}$ Moser, Teutsches Hof-Recht, 237-38. 
noticeably increased the splendor of the court and, no less importantly, strengthened the legitimacy of power. In Vienna, the Royal Hungarian Bodyguard became the first formation consisting exclusively of noblemen. Then in 1763, the guard unit "Arcièren" was added to it under King of the Romans, the heir to the throne of the Holy Roman Empire. 5

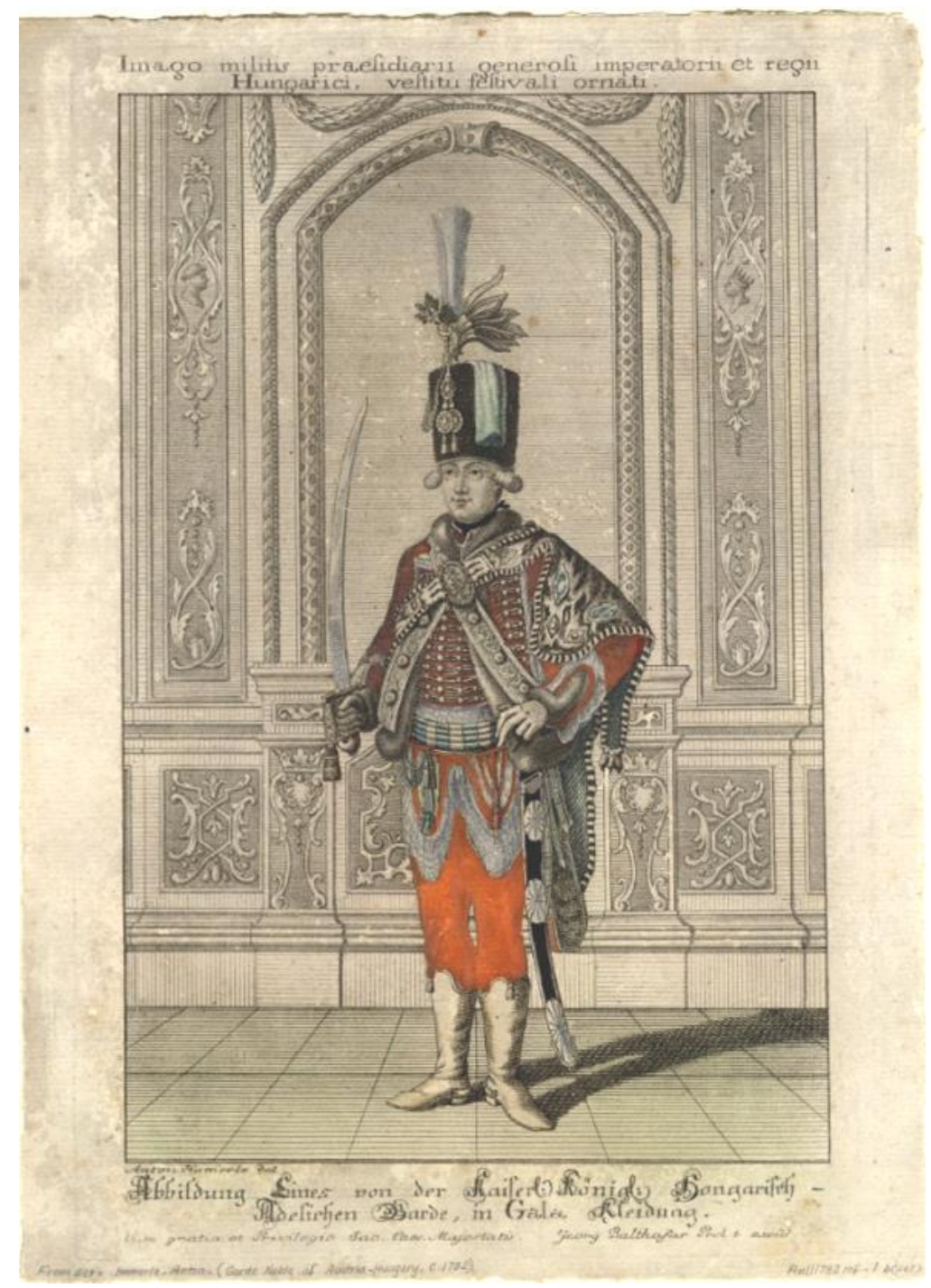

A. Hamerle. Image of a guardsman of the Imperial-Royal Hungarian Bodyguard wearing a full-dress uniform.

Source: Brown Digital Repository. Brown University Library. https://repository.library.brown.edu/studio/item/bdr:225656/

5 E. Paskovits, Die erste Arcièrenleibgarde Seiner Majestät des Kaisers und Königs. Ein Rückblick auf ihre 150-jährige Geschichte (Wien: Selbstverlag der k. k. Ersten Arcièrenleibgarde, 1914). 
The Royal Hungarian Bodyguard hads been quite well researched both in Hungarian and in Austrian historiography, ${ }^{6}$ but for a better understanding of the principles of the functioning of this institution, especially by the readership in other countries, it is necessary to clarify a number of issues. Using previously unknown sources, this article will show the role of the Guard (as an institution for the transfer of the nobility culture. Primary attention is supposed to be paid to the motivation for the establishment of the Guard, its functioning, and the role of the Royal Hungarian Bodyguard in the life and career of some guardsmen.

\section{Establishment and purposes}

The idea of establishing the Royal Hungarian Bodyguard appeared long before 1760. The first known mention of an institution with such functions dates back to 1711-12, the time of the signing of the Treaty of Szatmár, which ended the antiHabsburg Liberation War that unfolded in the Kingdom of Hungary in parallel with the War of the Spanish Succession under the leadership of Prince Ferenc II Rákóczi (1703-11), and thus opened a new page in the history of relations between the Hungarians and the Habsburgs. ${ }^{7}$ In a memorandum addressed to the Viennese authorities, the anonymous author - apparently a Catholic member of the court circles - outlined his views on the reasons which led to the Rákóczi uprising and possible ways to achieve long-term consolidation. ${ }^{8}$ The second item in the series of the proposed measures was the establishment of a Hungarian "guard," or

a cadet corps, where young noblemen would be brought up in true German ways and would be sent to war. ${ }^{9}$

${ }^{6}$ Without pretending to be complete, I will mention only a few works: A. Ballagi, A magyar királyi testőrség története, különös tekintettel irodalmi müködésére (Pest: Légrády testvérek, 1872); K. Tisza-Beői Hellebronth, szerk., A magyar testörségek névkönyve 1760-1918 (Budapest: Stádium, 1940); R.M. Urrisk-Obertyński, Die k. u. k. Leibgarden, 57-94.

${ }^{7}$ I. Szijártó, "The Rákóczi Revolt as a successful rebellion," in Resistance, rebellion and revolution in Hungary and Central Europe: Commemorating 1956, ed. L. Péter and M. Rady (London: Hungarian Cultural Centre London, 2008), 67-76.

${ }^{8}$ Családi fondok. Levéltárak [Family foundations, archives]. Kollonics család [The Kollonic family]. P 1901, I. s. d., Nr. 13. Magyar Nemzeti Levéltár Országos Levéltára, [Hungarian National State Archives] (MNLOL), Budapest, Hungary. The memorandum is entitled "Reflexiones. Woher die Zeitherige Rebellion in Königreich Hungarn entstanden und wie disemmalokünfftig ab und dem Lande in besten Stand wieder zu haltensey" [Reflections. Where did the recent uprising in the Hungarian kingdom come from and how to prevent this evil in the future and return the country to its former prosperity]. The original in German is published in: Zs. Kökényesi, "Helyzetértékelés és konszolidációs javaslatok. Egy 1711 körüli emlékirat tanulságai," (Fons, no. 4 (2020): 291-304.

${ }^{9}$ See P 1901, I. s. d., Nr. 13, MNL OL. 
According to the author, by means of the establishment of such a corps, more active involvement of young Hungarian nobles in the service in the acting army, and opening up the prospects of relatively rapid acquisition of officer ranks and career growth, the government would win the loyalty of the nobility. The next item of the project proposed the establishment of a knights' academy ("Ritterakademie"). Not only would it help to "enculturate" the nobility, but it would also encourage them to do service, useful to the sovereign and to the fatherland. ${ }^{10}$

Similar thoughts were voiced by the advisers who were part of the monarch's inner circle. After the liberation of the Hungarian Kingdom from Ottoman rule and the suppression of the Rákóczi's War of Independence, they proposed to implement the model of a paramilitary noble society in the kingdom. The history of Hungary in the $17^{\text {th }}$ century consisted of continuous military conflicts: some of them were directed against the Ottoman Empire, others (with varying degrees of support from society), against the rule of the Habsburgs. In the $18^{\text {th }}$ century, the balance of power swayed in favor of the court. Charles VI (1711-40) and especially his daughter Maria Theresa (1740-80) rejected the policy of forced centralization and tried to win the loyalty and support of the nobility by more sophisticated means. In the context of such a policy, the life guards could play a special role, and the key figures in the monarch's entourage insisted on its establishment. During the period of consolidation that followed the signing of the Treaty of Szatmár, Count Imre Csáky (1672-1732), the Bishop of Kalocsa, cardinal, one of the most prominent Hungarian politicians of that time, strongly supported the idea of establishing a guard recruited from the Hungarian noblemen at the court, but in the reign of Charles VI it never happened. ${ }^{11}$ At the beginning of the reign of Maria Theresa, in the first years of the War of the Austrian Succession (1740-48), the military and political weight of the Hungarian estates in the Habsburg Monarchy increased significantly. At the Coronation Diet in 1741 along with the utopian idea of building a royal residence in Buda, the idea of creating a Hungarian guard was put forward. ${ }^{12}$ In the first half of the 1740s, plans for the formation of guards were discussed repeatedly. Among others, Christian Gottlob Richter (1745-91), a historiographer of the first years of Maria Theresa's reign, wrote about those plans in the monumental work The History and Deeds of Maria Theresa. ${ }^{13}$ The Royal Hungarian Bodyguard was established two decades later, at the height of the Seven Years' War (1756-63).

${ }^{10}$ See MNL OL. - P 1901. I. s. d. - Nr. 13.

11 Ö. Málnási, Gróf Csáky Imre bíbornok élete és kora (1672-1732) (Kalocsa: Csáky család kiadása, 1933), 148.

${ }^{12}$ Ballagi, A magyar királyi testörség, 28.

${ }^{13}$ Richter had information that the plans for the establishment of the Hungarian Noble Guard were discussed as early as 1744; the plans were quite specific and found support from the Empress and her advisers, "but the Austrian nobility did not like this," and made every effort to prevent this. 
On behalf of Maria Theresa, the Hungarian Court Chancellor Count Miklós Pálffy (1710-73) presented a draft proposal for the establishment of the Royal Hungarian Bodyguard on October 25, 1759. ${ }^{14}$ According to the chancellor, the new institution was created in order to take care of the interests and prosperity of the Kingdom of Hungary: young nobles of 18-20 years of age would get to Vienna, find themselves in close proximity to the court, learn the customs and morals there, improve in the exercises and sciences necessary for a future military or civil career. Even then, Pálffy considered the guards as a kind of school, or rather an educational institution, which would become an important addition to the number of already operating metropolitan noble academies. At that time there were three of them in Vienna: Theresianum, Löwenburg Boarding School, and Savoyard Academy, all of which were attended by the children of Hungarian magnates and nobles, and the first two offered scholarships to Hungarian pupils. ${ }^{15}$ All three educational institutions performed a complex function: they were created following the example of foreign knight academies to transfer the latest knowledge to young people and encourage them to enter the civil service. Pálffy believed that

[youngsters] in these academies are trained in the sciences but do not receive the necessary skills of behavior; they have no opportunity to form ideas about what awaits them in adult life, therefore, upon returning home, they quickly forget the little that they learned in the academies due to lack of practice, then get married and finally, irrevocably lose everything that could be useful for the sovereign, the fatherland, and themselves. ${ }^{16}$

See [Ch. G. Richter], Geschichte und Thaten der Allerdurchlauchtigsten und Großmächtigsten Fürstin und Frau Maria Theresia jetztregierenden Königin in Hungarn und Boeheim... s. 1. 1745, vol. 4, 45-46.

${ }^{14}$ J. Illéssy, “A magyar királyi nemes testőrség felállítása 1760,” Hadtörténelmi Közlemények, 8. évf, 1. sz. (1895): 370-75. Excerpts from the project are given in the two-volume history of the Noble Guard by Johann Baptist Skall (1774-1832), Director of the Chancellery of the Master of the Horse Office (1813-1820). See J.B. Skall, "Geschichte, Administrazion und Einrichtung der König. Ungar. Adel. Leibgarde.” Cod. Ser. No. 3919, S. 22. Handschriftensammlung, Österreichische Nationalbibliothek. The work, which remained a manuscript, contains references and lengthy quotes from sources, including the documents that have not survived to this day. For more, see also G. Mraz, "Johann Baptist Skall - Geschichte, Administration und Einrichtung der königlich ungarischen adeligen Leibgarde," in Forscher - Gestalter - Vermittler. Festschrift Gerald Schlag, ed. W. Gürtler (Eisenstadt: Amt der Burgenländischen-Landesregierung, 2001), 239-52.

${ }^{15}$ For more in Russian, see O.V. Khavanova, Fathers' merits and sons' talents: Hungarian nobles in educational institutions of the Habsburg Monarchy, 1746-1784 [in Russian] (St Petersburg: Aleteiya, 2006). On the representation of Theresianum, see Zs. Kökényesi, "Das Bild und die Repräsentation des Theresianums in der Öffentlichkeit des 18. Jahrhunderts," Wiener Geschichtsblätter, Jg. 70, Nr. 3 (2015): 263-80.

${ }^{16}$ Skall, "Geschichte, Administrazion und Einrichtung der König," 25-26. 
In other words, Pálffy gave the Guard an exceptional role in shaping the mentality and way of thinking of the Hungarian nobility. From the point of view of career opportunities, the chancellor believed that the guard would take a central place in the training of personnel for Hungarian regiments and become, so to speak, a school of officers ("Pflanzschule der Offiziere"). ${ }^{17}$

Initially, M. Pálffy intended to recruit guardsmen from young men aged between 18 and 20, but on the advice of Obersthofmeister (Lord Steward of the Household) Count Corfiz Anton von Uhlfeld (1699-1769), he raised the age of enrolment to 20 years. ${ }^{18}$ The chancellor considered it extremely important to recruit young Protestant nobles, and the Generalkriegskommissariat supported this idea. However, at Uhlfeld's insistence, it was decided that the proportion of Protestants in the Guard should not exceed one-third of the personnel. ${ }^{19}$ Subsequently, twice a year starting in the autumn of 1760, the office of the Obersthofmeister issued a decree which allowed Protestant guardsmen to attend divine services in the Hungarian free royal city of Sopron located near Vienna. ${ }^{20}$ In the general context of the recatholization policy, recruiting Protestants into the guard and permitting them to practice their religion was an important gesture of the Habsburg government.

Count Wenzel Anton von Kaunitz (1711-94), the Chancellor of State and the first adviser to Maria Theresa in matters of domestic and foreign policy, considered it necessary to state his opinion on the establishment of the Royal Hungarian Bodyguard in a note dated April 16, $1760 .{ }^{21}$ During his time as ambassador to Paris in 1750-53, Kaunitz had already proposed to establish a noble guard ("garde noble"), designed to ensure the security of the ruling house, but in those years it did not come to the implementation of the project. The Chancellor of State referred to the new institution as useful since the guard added splendor to the court and was supposed to have a beneficial effect on the Hungarian nobility. ${ }^{22}$ Kaunitz considered it necessary to emphasize that the costs of its maintenance should be borne by the Hungarian

${ }^{17}$ Skall, "Geschichte, Administrazion und Einrichtung der König," 27. On the officer careers of the former guardsmen, see O. Khavanova, "Fascination with Uniform? Choosing between Military and Civil Careers in the Eighteenth-Century Habsburg Monarchy," Hungarian Studies, vol. 32, no. 1 (2018): 125-27.

${ }^{18}$ Ibid., 26, 71.

${ }^{19}$ Ibid., 53, 72 .

${ }^{20}$ Ibid., 215.

${ }^{21}$ Ibid., 86-97. The work by J.B. Skall is of even greater importance because neither Hungarian nor Austrian scholars were aware of that note written by V.A. Kaunitz, and the original from the fonds of the State Chancellery has not survived. According to the inventory, this document was previously stored in the fonds of the Austrian State Archives. See Haus-, Hof- und Staatsarchiv. Österreichisches Staatsarchiv, Vienna, Austria. Staatskanzlei Vorträge, Kt. 87, Fol. 256 r.

${ }^{22}$ Skall, "Geschichte, Administrazion und Einrichtung der König," 87-88. 
counties (administrative territorial units of the kingdom). ${ }^{23}$ The Chancellor went on to express his concern that the nobles of the Austro-Bohemian Hereditary Provinces might be envious of the guard because no such institution was provided for their sons and also because the guard increased the chances of a successful career only for Hungarian nobles. Kaunitz did not rule out that new guard regiments could be founded in the future, but in the meantime he pointed out that young nobles from the hereditary provinces had military academies that gave brilliant education and opened up excellent career opportunities, which their parents should not forget. ${ }^{24} \mathrm{He}$ also noted the timeliness of the establishment of the guard in terms of manning the army and improving the training of the officer corps of the Habsburg Monarchy at the height of the war with Prussia.

The preparatory period took about a year during which the issues of funding, legal status, recruitment of guardsmen, construction of the palace, purchase of horses and uniforms, etc. were resolved. The profile and legal status of the Guard was defined in the privilege issued on September 11, 1760, according to which the Royal Hungarian Bodyguard were a full-fledged military and court institution with the personnel of 120 persons recruited in the Transylvanian, Croatian and Hungarian counties. ${ }^{25}$ The mention of the Transylvanian nobles was not a matter to be taken for

23 Skall, "Geschichte, Administrazion und Einrichtung der König,” 88-89.

${ }^{24}$ Ibid., 91. At that time, the Hungarian nobility was indeed reluctant to attend the Military Engineering Academy established in 1717 in Vienna or the Theresian Military Academy founded in 1751 in Wiener Neustadt. See K. Kissné Bognár, Magyarországi diákok a bécsi tanintézetekben, 1526-1789 (Budapest: Eötvös Loránd Tudományegyetem Levéltára, 2004), 321-34, 345-62. After the 1755 abolition of the Chaos Foundation (founded in 1664 by Johann Richthausen, Baron Chaos), which financed the training of the sons and orphans of Austrian, Hungarian and Croatian noblemen and officers, fellows from the Kingdom of Hungary continued their studies at the Vienna Engineering Academy. See O. Khavanova, "Eine universitäre Lehrveranstaltung als universales Instrument: Joseph von Sonnenfels und die administrative Elite der Habsburgermonarchie." In Die Anatomie frühneuzeitlicher Imperien. Herrschaftsmanagement jenseits von Staat und Nation, ed. by S. Wendehorst (Berlin; München; Boston: Walter de Gruyter, 2015), 106. To learn more on the training of Hungarian nobility in Vienna, including the calculation of the number of Hungarian nobles in Theresianum, see O. Khavanova, "Der ungarische Adel am Wiener Theresianum im 18. Jahrhundert: die sozialen und kulturellen Grenzen einer politischen Nation," in Österreichischungarische Beziehungen auf dem Gebiet des Hochschulwesens = Osztrák-magyar felsőoktatási kapcsolatok, ed. by Zs.K. Lengyel, J.Zs. Nagy, G. Ujváry (Székesfehérvár: Kodolányi János Föiskola; Budapest: Eötvös Loránd Tudományegyetem Könyvtára, 2010), 107-22. For more on the military academies, see T. Shek Brnardić, The Enlightened Officer at Work: the Educational Projects of the Bohemian Count Franz Joseph Kinsky (1739-1805) (PhD thesis, Central European University, 2004).

${ }^{25}$ Hadtörténeti Levéltár [Military Historical Archives] (HL), Budapest, Hungary. „A királyi magyar nemesi testörség iratai" [Documents of the Hungarian Noble Guard], 1760. Kt. 1, Nr. 3. 
granted, since the Kingdom of Hungary and the Principality of Transylvania were considered special state entities at that time, but Chancellor Gábor Bethlen (1712-68) and Governor László Kemény did everything possible so that representatives of the three political "nations" (Hungarians, Saxons and Székelys) could become guardsmen. ${ }^{26}$ The establishment of the Royal Hungarian Bodyguard was accompanied by lavish celebrations held on September 27-28, 1760 in Pressburg, the administrative capital of the kingdom (now Bratislava, Slovakia). ${ }^{27}$ The event attracted the attention of the public. The supplement to the official court newspaper Wienerisches Diarium [Viennese Diary] published a detailed program of the event, and the Royal Hungarian Bodyguard called nothing else than

an undertaking that will serve exclusively for the honor, decoration and benefit of the glorious Hungarian nation. ${ }^{28}$

The spectacular Viennese debut of the Noble Guard took place a week later, on October 6, 1760, during the long-awaited lavishly celebrated festival on the occasion of the marriage of Archduke Joseph and Isabella of Parma. ${ }^{29}$

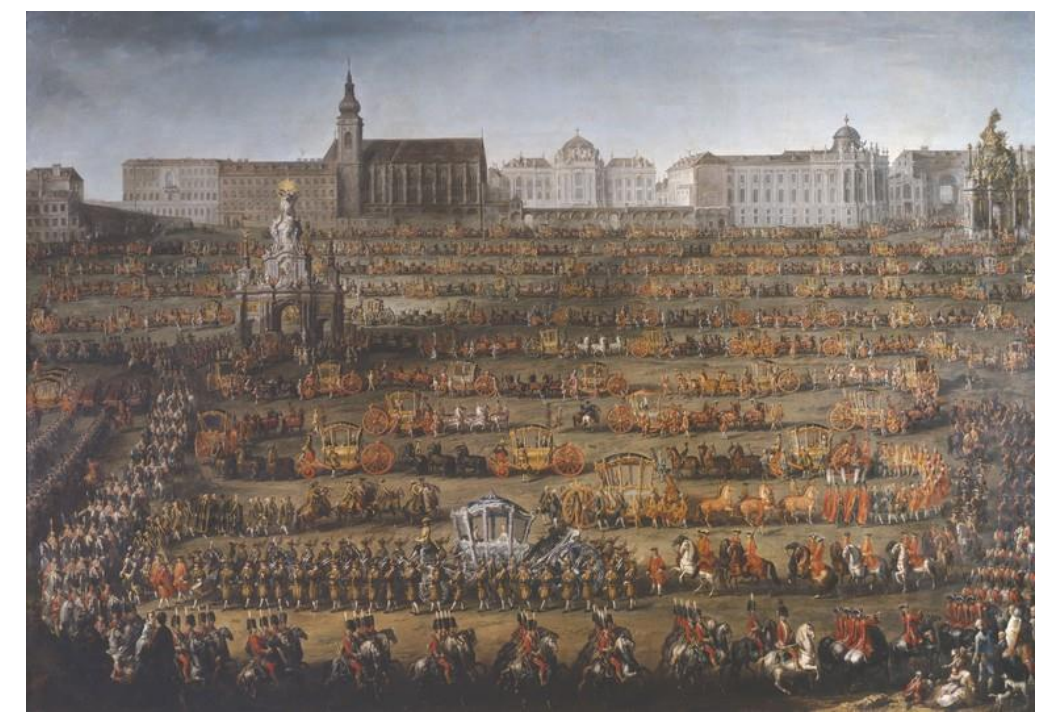

M. Meytens. Ceremonial arrival of Isabella of Parma in Vienna.

The Royal Hungarian Bodyguard are among the participants in the procession.

Source: https://upload.wikimedia.org/wikipedia/commons/2/25/Martin_van_Meytens_012.jpg

Subsequently, the number of the guardsmen was reduced to 90 in 1769 ; to 80 in 1770 ; to 60 people in 1778.

${ }^{26}$ Skall,“Geschichte, Administrazion und Einrichtung der König,” 17-18; MNL OL. Erdélyi Kancellária. B 2. 1760, no. 342.

${ }^{27}$ Skall,"Geschichte, Administrazion und Einrichtung der König,” 194-207.

${ }^{28}$ Wienerisches Diarium, October 4, 1760.

${ }^{29}$ F. Krudy, comp., Báróczy Sándor feljegyzései a Magyar Nemesi Testőrség életéböl 17601800-ig, trans. J.K. László (Budapest: M. Kir. Hadilevéltár, 1936), 17. 


\section{Direct and indirect introduction to culture}

On the one hand, the daily routine of the guardsmen consisted in performing palace guard duty, where they provided protection and a magnificent escort to the members of the ruling house in the capital and on the road. On the other hand, for young Hungarian noblemen, the guard opened up opportunities to become directly and indirectly introduced to culture. The duties officially assigned to the guardsmen included

during the hours off duty, to perfect themselves in the languages spoken at the imperial royal court and in important and useful sciences. ${ }^{30}$

Young noblemen were supposed to study German and French, practice "noble exercises" (dancing, fencing, horse riding), and great importance was given to the study of military engineering. The guardsmen were also given an opportunity to study optionally ${ }^{31}$ English and Italian, law, and political and cameral sciences. ${ }^{32}$ Thus, in accordance with the original plan, the guard turned into a cultural and educational institution which made it possible to study subjects that were not taught at that time in Jesuit gymnasiums but could later be useful both in state and in military service. Similar education was given in foreign (French, German, Italian) knight academies, and the characteristic combination of the curriculum with the noble education was already observed in the first noble guards. At the court of Augustus II the Strong, the guard service was supplemented by a training program for officers; teachers of fencing, foreign languages and dance were employed for cadets; the latter were also taught geography, mathematics, history, ethics, and the principles of architecture. ${ }^{33}$ The Habsburgs, who were related to the Wettin dynasty, could take that as a model when establishing the noble guard. Of all the guard units at the court of Vienna, the desire to supplement the service with an educational program was characteristic not only for the Hungarian regiment, but also for the Galician Guards established in $1782 .^{34}$ Within five years of court service there, Polish gentry also mastered a wellwritten course of sciences which included foreign languages, mathematics, philosophy, law, and state sciences.

${ }^{30}$ HL. A királyi magyar nemesi testőrség iratai. 1760. Kt. 1, Nr. 5.

${ }^{31}$ A magyar testörségek névkönyve, 47-48.

${ }^{32}$ Political and Cameral Sciences was an academic discipline in the second half of the $18^{\text {th }}$ century, within the framework of which basic knowledge about the state, society, economics and finance was given.

${ }^{33}$ Moser, Teutsches Hof-Recht, 238.

34 A. Gestrich, "Die galizischen adeligen Leibgarden am Wiener Hof. Ein Beispiel habsburgischer Inklusionspolitik nach den Teilungen Polen-Litauens," Militär und Gesellschaft in der Frühen Neuzeit, Jg. 17, no. 1 (2013): 41-64. 
For young noblemen, the years of service in the guard meant not only training in the literal sense of the word, but also familiarizing themselves with the opportunities for cultural development and acquiring useful connections that Vienna offered. Regular attendance at the theatre was considered mandatory, and some highly educated and well-connected young people even managed to get into Masonic lodges. The lists of many lodges include one or two names of Hungarian guardsmen, especially in the first half of the 1780s (the heyday of the Viennese Masonic movement). ${ }^{35}$ For example, Imre Berzeviczy (1745-96) was a member in the Lodge "Zu den drei Adlern" [Towards three eagles]; Bálint Bacskády (1750-1815), in "Zur gekrönten Hoffnung" [Towards the crowned hope] as well as József Kuzmich (1741?) who did not stop membership in the lodge even after he retired to his native Debrecen where he received the post of councilor. ${ }^{36}$ From the point of view of Masonic connections, it is equally important that many guardsmen attended the meetings of such an intellectual center of Vienna as the lodge of Ignaz von Born (1742-91) "Zur wahren Eintracht" [Towards true Harmony]. Among them were the future clerk of the Transylvanian Court Chancellery József Danckai (1752-?) and József Dóczy (1741-1825) who made a brilliant career as an officer. ${ }^{37}$

For the provincial noblemen, Vienna with its 200-thousand population was a kind of a window into Western Europe and metropolitan culture. As guardsmen, young people visited not only Vienna and Pressburg, but also Milan, where a detachment of 26 Hungarian guardmen was stationed in 1771-78 under the Governor of Lombardy Archduke Ferdinand. ${ }^{38}$ In 1778, Joseph II ordered to attract the most intelligent guardsmen to the duties of couriers, which not only increased their status but also expanded their geographical knowledge and general outlook. Vendel Batsák (17571840), a native of the Pressburg county, visited Belgium, Italy, France, Poland and Russia as a guard courier. He wrote the following about a trip to Italy in 1784:

[Leopold, Grand Duke of Tuscany] was extremely kind to me; when he learned that I had not seen the sea, he sent me to his Mediterranean port city of Livorno. There I

${ }^{35}$ E. Rosenstrauch-Königsberg, Freimaurerei im josephinischen Wien. Aloys Blumauers Weg vom Jesuiten zum Jakobiner. Wiener Arbeiten zur deutschen Literatur. Bd. 6 (Wien; Stuttgart: W. Braumüller, 1975).

36 Österreichisches Staatsarchiv, Wien. Haus-, Hof- und Staatsarchiv. Kabinetsarchiv. Vertrauliche Akten, Kt. 72, Konv. 7, Fol. 144; 246-47.

37 H.J. Irmen, Die Protokolleder Wiener Freimaurerloge "Zur Wahren Eintracht" (17811785), Schriftenreihe der Internationalen Forschungsstelle Demokratische Bewegungen in Mitteleuropa 1770-1850, Bd. 15 (Wien: Peter Lang, 1994), 348.

${ }^{38}$ A magyar testörségek névkönyve, 14. 
saw the sea for the first time, tasted the sea water, it turned out to be bitter and salty. ${ }^{39}$

The following year Batsák visited Northern Italy again:

The Emperor sent me to Milan to see this city, and ordered my comrade Batskády, ${ }^{40}$ who had arrived there earlier, to show me all the sights (there are no words to describe how graciously the Emperor treated the Hungarian guards). ${ }^{41}$

These and similar trips helped young people gain experience and get new impressions.

The picture will not be complete if we do not note that the freedom of maneuver and the ability of the young guardsmen to satisfy their intellectual needs largely depended on the current moment in the policy of the Habsburg government and on the severity of censorship. For example, in 1767 through the office of the Obersthofmeister, Maria Theresa issued a decree prohibiting freethinking (Freigeisterei) and ideas directly opposing the Catholic doctrine, which at that time were in circulation at the court and among the guardsmen. ${ }^{42}$ The owners of such books were given eight days to burn them; otherwise the violators would be dismissed and punished. Or, for example, after the issue of the Masonic patent (1785) by Joseph II, joining the lodges became difficult.

The Guard was not only a court or educational institution, but also a military organization that required serious discipline and order from the guardsmen. Many people found it difficult or impossible to meet such requirements. In the archives of the Royal Hungarian Bodyguard, there is a "Protocol of Disciplinary Penalties" (Straffprotokolle), which details the violations, debts and minor misdemeanors of the guardsmen who were eager to have fun in the imperial capital. For example, on February 2, 1771, Pal Buday (1748-?) returned to the barracks after the gate had been closed, was rude to the guard and was sent to the guardhouse for 24 hours. ${ }^{43}$ Antal Tomcsányi (1746-93), who was later assigned to the Milan Guards regiment, received a similar punishment: he was found in a room smoking and eating meat (which was allowed only for the sick on that day of the week). ${ }^{44}$ There were also

39 S. Nyakas, "Benefai Batsák Vendel utazásai," Közlemények a pécsi Erzsébet Tudományegyetem Könyvtárából, 14. sz. (1932): 1-8.

${ }^{40}$ The above-mentioned guardsman Bálint Bacskády.

${ }^{41}$ Nyakas, "Benefai Batsák Vendel utazásai," 4.

${ }^{42}$ HL. A királyi magyar nemesi testőrség iratai, 8/4.

${ }^{43}$ HL. A királyi magyar nemesi testőrség iratai, 8/4, Bd. 200, Fol. 1r.

${ }^{44}$ Ibid., Fol. 1v. 
more serious violations: gambling debts (gambling was prohibited) and frequent scuffles.

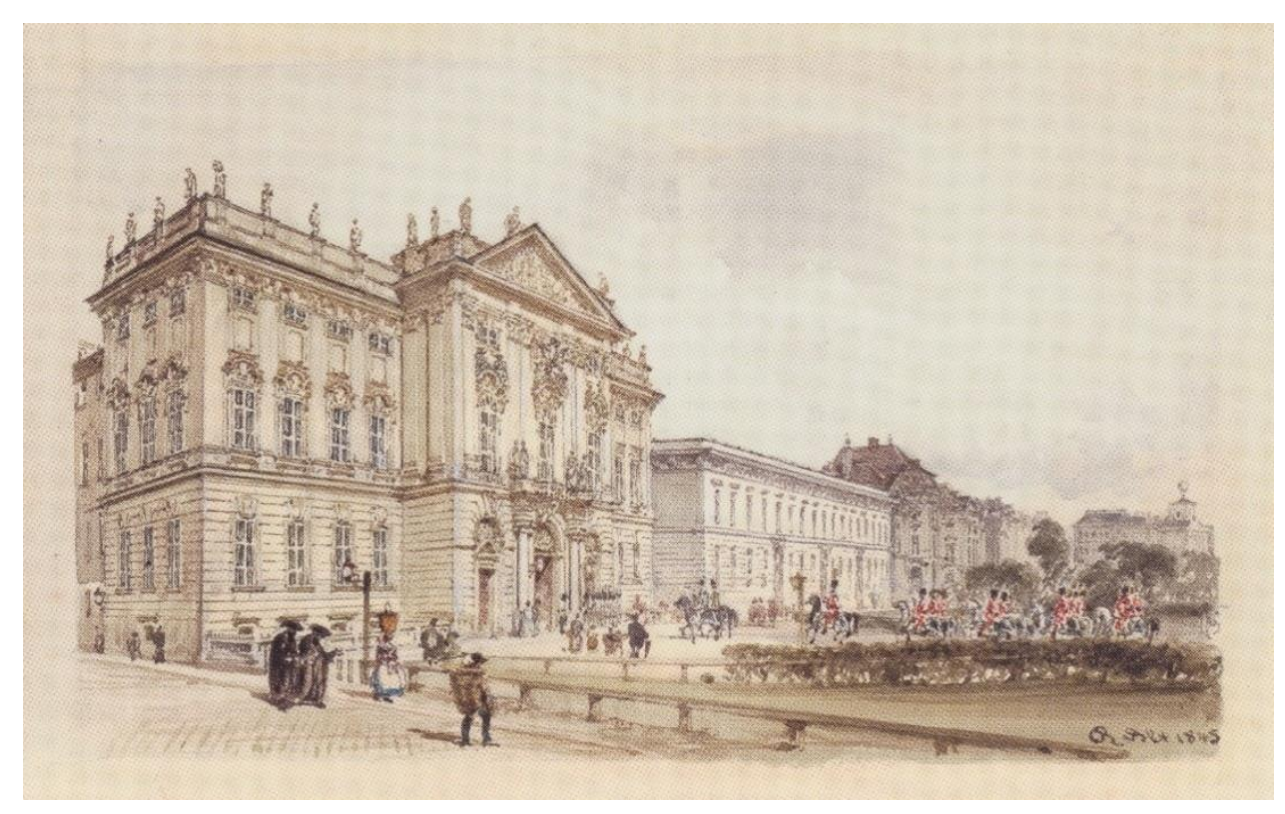

R. von Alt. Trautson Palace (1845).

In 1760-1848 it served as the residence for the Royal Hungarian Bodyguard.

Source: URL: https://upload.wikimedia.org/wikipedia/commons/5/59/Rudolf_von_Alt__Das_Palais_Trautson_in_Wien_-_1845.jpeg

\section{The place of the guard service in the careers of Hungarian noblemen}

The Royal Hungarian Bodyguard united young people from different parts of the kingdom, who differed in origin, social status and worldview. Natives of Transylvania, Croatia and Hungary served in the regiment, and both Catholics and Protestants were among them. Most of the guardsmen came from middle-rank nobility; gentry and aristocrats were less common. Several examples of typical careers with a primary focus on the period of study and the beginning of the service are considered below.

With regard to the aristocrats in the Guard, it must be emphasized that they could perform not only the duties of guard officers but also of ordinary guardsmen. Even in the project of 1759, the chancellor Miklós Pálffy proposed the enlistment of magnates' sons in the Guard. The top of the ruling class of the Kingdom of Hungary consisted of large landowners of Western Hungary, the families who owed their rise to the Habsburgs: Erdődy, Esterházy, Pálffy. Their representatives can be found both in the ranks of the Guards officers and among the command; the rank-and-file guardsmen were also recruited from the side lines of such families, especially in the early years of the institution. One of the richest and most influential families in Hungary were the Batthyány: at the time of the establishment of the guard, the highest position of the kingdom, the post of nador (royal palatine) was held by Count 
Lajos Batthyány (1696-1765), and his younger brother Károly (1697-1772) served as Obersthofmeister to Archduke Joseph and as a conference minister at the court of Vienna. Lajos and Károly's cousin Imre Ernő Batthyány (1701-74) was a judge of the Septemvirate court and Master of the Table (Magister Dapiferorum). ${ }^{45}$ His father, Count Zsigmond Batthyány (?-1728), gave his son a brilliant home education, then sent him to the Jesuit gymnasium in Köszeg, located near to his ancestral estates, then the young man studied rhetoric and philosophy in Graz and law at the Benedictine University in Salzburg. ${ }^{46}$ Imre Batthyány also wanted to give his sons an excellent education, but the material possibilities were limited and it was not a question of visiting foreign universities or a grand tour. He preferred to give the children home education, and then send them to one of the Viennese noble academies. The scholarship established in Vienna for the Hungarian nobles was very helpful, and he managed to get it for two of his four sons. József (1737-1806), the future vicepresident of the Hungarian Treasury Chamber, and Ignác (1741-98), the future Transylvanian bishop, studied at Theresianum as paid students; Antal (1747-1814), as a scholarship holder. ${ }^{47}$ Imre Batthyány Jr. (1744-1819) studied at the gymnasium in Graz; his father could not get him a scholarship place at Theresianum so he had to settle for a more modest place, Löwenburg Bording School. At the end of the course of sciences, Imre was enrolled in the Royal Hungarian Bodyguard, where he served for a little more than two years. In the future, he chose a military career but did not reach a high rank.

More successful was the military career of Baron Imre Révay (1751-91), who was promoted to lieutenant colonel and awarded the Knight's Cross of the Order of Maria Theresa. ${ }^{48} \mathrm{He}$ came from an ancient ramified family, but it was standing behind many magnate families in the hierarchy. His father Mózes owned modest

${ }^{45}$ F.K.Wißgrill, Schauplatz des landsässigen Nieder-Oesterreichischen Adels vom Herren- und Ritterstande von dem XI. Jahrhundert an, bis auf jetzige Zeiten: Vol. I (Wien: Gedrucktbey F. Seizer, 1794), 315.

${ }^{46}$ I.E. Batthyány studied in the class of grammar and poetics of the Köszeg gymnasium from 1717 to 1719. See Köszegi Fióklevéltár [Köszeg branch] (KFL). Magyar Nemzeti Levétár Vasmegyei Levéltára, [Archive of the Vash committee of the Hungarian National Archives] (MNLVaML), Sopron VIII, 52, Fol. 86 r - 93 r.; J. Varga, Magyarországi diákok a Habsburg Birodalom kisebb egyetemein és akadémiáin 1560-1789 (Budapest: Eötvös Loránd Tudományegyetem Levéltára, 2004).

47 See Kissné Bognár, Magyarországi diákok, 337-39. In the proposition of the Hungarian Court Chancellery, the names of the Batthyány brothers are not mentioned, but it is known about Antal that he studied at Theresianum. See MNL OL. Magyar kancelláriai levéltár. A Magyar Királyi Kancellária regisztratúrája Originales referadae. [Archive of the Hungarian Chancellery. Registry Office of the Hungarian Court Chancellery. Originals of acts]. A 1, 1762, no. 202.

48 J. Hirtenfeld, Der Militär-Maria-Theresien-Orden und seine Mitglieder (Wien: K-K. Hof und Staatsdruckerei, 1857), 305. 
estates in the Turóc county located far from Vienna and in the Szepes (Zips) region. ${ }^{49}$ In 1761-67, Imre received an excellent education at the Jesuit gymnasium in Nagyszombat (now Trnava, Slovakia), where he was a royal scholarship holder in the noble convictus. ${ }^{50}$ After graduating from the Gymnasium, Imre Révay briefly studied at the Theresian Military Academy in Wiener Neustadt and then he joined the Puebla Infantry Regiment. ${ }^{51}$ He spent three years in the Royal Hungarian Bodyguard, where he was assigned to the Milanese detachment.

From the point of view of useful acquaintances and integration into the court society, the Royal Hungarian Bodyguard was especially attractive to nobles and aristocrats from eastern Hungary and Transylvania. Without the Royal Hungarian Bodyguard, a young Protestant from Transylvania, Baron József Naláczy (17481822), would never have been able to spend two years in the Habsburg capital and to take full advantage of the opportunities to improve his cultural level. ${ }^{52}$ The young man lost his father at an early age, finished his studies at a reformed collegium in Nagyenyed (now Aiud, Romania), before enlisting in the guard, he managed to work as a notary (small clerk) at the Transylvanian Royal Court of Justice. A decisive role in the fact that the Protestant baron from Transylvania came to Vienna was played by the recommendation of the governor, Count András Hadik (1710-90), who paid tribute to the exceptional abilities of the young man and the political loyalty of his family in a letter of reference to the captain of the Noble Guards Prince Miklós Esterházy (1714-90). ${ }^{53}$ Naláczy liked the service in the Noble Guard; he spent seven years in Vienna. The accumulated experience was useful later both in the military and in the civil service. The pinnacle of his career was the position of ispán (Lord Lieutenant) of the Zaránd county, received in $1792 .{ }^{54}$ Naláczy went down in history

49 Z. Fónagy, A nemesi birtokviszonyok az úrbérrendezés korában, Magyar Történelmi Emlékek. Adattárak (Budapest: Magyar Tudományos Akadémia Bölcsészettudományi Központ Történettudományi Intézete, 2013), 1320.

50 MNL OL. Magyar kancelláriai levéltár. A Magyar Királyi Kancellária regisztrátúrája Originalesreferadae [Hungarian Chancellery Archives. Registry of the Royal Hungarian Chancellery. Originals of Acts]. A 1, 1762, no. 217; Nagyszombati adattár. A nagyszombati jezsuita gimnázium diáksága. Anyakönyvi adattár (1616-1772) [Nagyszombat database. Students of the Nagyszombat Jesuit Gymnasium. Matricular database (1616-1772)], no. 30160, accessed July 24, 2020, https://library.hungaricana.hu/hu/view/JezsuitaGimnaziumokDiakjai_2_Nagyszombat/?pg= $0 \&$ layout $=\mathrm{s}$

${ }^{51}$ A magyar testörségek névkönyve, 317.

52 Ibid., 270.

${ }^{53}$ MNL OL. Családi fondok, levéltárak [Family fonds and archives]. Családi levéltárak [family archives]. Esterházy család hercegi ága [The princely branch of the Esterhazy clan]. Repertóriumok [Repertories]. P 108, rep. 98, fasc. M., no. 17. MNL OL.

${ }^{54}$ A magyar testörségek névkönyve, 270. 
not only as a statesman but also as a key figure in the Transylvanian Reformed community, and also as the author of a number of literary works and translations.

For particularly gifted and successful nobles, the Royal Hungarian Bodyguard became a means of improving the social situation, as it happened in the case of Anatal Lipthay (1745-1800), a middle-class nobleman from the Nógrad county. ${ }^{55}$ His studies and service were extremely successful for him: he graduated from the gymnasium at the center of Catholic education in Hungary in Trnava, and then attended a rhetoric class in Presburg for two years. ${ }^{56}$ The family believed that the young man would choose a clerical path. However, two of his brothers, Adalbert and Pál, became Catholic priests, while Antal chose a secular career. ${ }^{57}$ In $1763-64$, he served as a minor clerk in the Council of Lieutenancy (Consilium Regium Locumtenentiale Hungaricum) and then on the recommendation of the Pressburg county, he was enlisted in the Royal Hungarian Bodyguard. ${ }^{58}$ After four years in Vienna, he did not return to the desk, but continued to serve in the army, where in 1788 he was awarded the Knight's Cross of the Order of Maria Theresa, received the title of baron, and in 1799 he reached the rank of lieutenant general. ${ }^{59}$ In his spare time, Lipthay was an active Freemason, at first, a member of the lodge "Zur Wachtsamkeit" [Towards vigilance], and in 1786 he was appointed deputy Grand Master of the Pest Lodge "Zur Grossmuth" [Towards generosity]. ${ }^{60}$ In the 1780 s, he began publishing battle reports and geographical maps but did not succeed.

Of course, most of the guardsmen were not recruited from the magnates, and subsequently they did not manage to become either barons or counts. The career of Pál Rosty (1745-1810) is much more typical. His well-to-do family came from the Vas county in Western Hungary, where they were actively involved in political life at the local and national levels for many generations. ${ }^{61}$ Pál's father Ferenc Rosty (1718-90), was a member of the county administration and represented the county at

${ }^{55}$ Skall, "Geschichte, Administrazion und Einrichtung der König,” 238.

${ }^{56}$ Nagyszombati adattár, no. 29271; Pozsonyi adattár A pozsonyi jezsuita gimnázium diáksága. Anyakönyvi adattár (1650-1773) [Presburg database. Students of the Presburg Jesuit Gymnasium. Matricular database (1650-1773)], no. 17507, accessed July 24, 2020, https://library.hungaricana.hu/hu/view/JezsuitaGimnaziumokDiakjai_3_Pozsony/?pg=0\&layout=s

${ }^{57}$ I. Nagy, Magyarország családai. Czímerekkel és nemzékrendi táblákkal, vol. 7 (Pest: Ráth Mór, 1860), 132.

58 Gy. Ember, A m. kir. Helytartótanács ügyintézésének története 1724-1848 (Budapest:

M. Kir. Országos Levéltár, 1940), 233.

${ }^{59}$ Hirtenfeld, Der Militär-Maria-Theresien-Orden, 243-44.

${ }^{60}$ L. Abafi, A szabadkömüvesség története Magyarországon, reprint ed. (Győr: Tarandus Kiadó, 2012), 277; Zs. Kökényesi, "Egyháziak, katonák, nemesek. Eszéki, károlyvárosi és selmecbányai szabadkőmüves páholyok tagjai 1785-ben," Polymatheia, sz. 3-4 (2020): 53-85.

${ }^{61}$ Fónagy, A nemesi birtokviszonyok, 1326. 
the Hungarian Diet of several convocations. ${ }^{62}$ Pál attended the Jesuit gymnasium in nearby Köszeg and then studied in Sopron. ${ }^{63}$ Soon the county recommended him to enrollment in the Royal Hungarian Bodyguard, where the young man served for five years. ${ }^{64}$ He chose a military career, but in 1795 it was cut short by his participation in a conspiracy of the so-called Hungarian Jacobins led by Ignác Martinovich. Rosty spent a year in prison and then returned to his native county, where he received a position of a judge. ${ }^{65}$

\section{Conclusion}

The most famous officers of the Royal Hungarian Bodyguard are György Bessenyei (1747-1811) and Ábrahám Barcsay (1742-1806), without whom the Hungarian literary Enlightenment would have been unthinkable. ${ }^{66}$ But the significance of the Royal Hungarian Bodyguard as a social institution cannot be reduced to these two names. In accordance with the original plan, the guard opened up the opportunity for lots of noblemen to raise their cultural level, allowed them to realize the dream of a grand tour or study abroad. Compared to the limited circle of magnates and nobles who managed to get into the Viennese noble academies, the guard opened its doors to dozens of Hungarians from remote corners of the kingdom. During the reign of Maria Theresa, their number including the officers of the guard was about four hundred, which is four times more than the number of Hungarian, Croatian and Transylvanian nobles in Theresianum during the same period (from 1760 to 1780). ${ }^{67}$ The guard played a crucial role in building closer contacts between the Habsburg capital and the Hungarian counties as well as in introduction of young Hungarians to Western and Central European culture. Those who happened to serve abroad or as couriers received even stronger intellectual impetus. On returning to their families and to their native counties, they shared their impressions with the provincial Hungarian society.

${ }^{62}$ I. Bezerédj, "Rosti Ferenc levelei az 1764-65. évi pozsonyi országgyülésből," Dunántúli Szemle, 10. évf., 1-2. sz. (1943): 4-20.

${ }^{63}$ In 1756 he finished elementary school (principista) in Köszeg, in 1757 he studied in grammar class (grammatista). See MNL VaML. KFL VIII. 52, Fol. 217 r - 220 v. In Sopron, he finished classes of syntax, poetics and rhetoric (syntaxis, poetica és rhetorica) in 1758-1760. See MNL Győr - Moson - Sopron Megye Soproni Levéltára. VIII. 52 (no pagination).

${ }^{64}$ A magyar testőrségek névkönyve, 320.

${ }^{65}$ K. Benda, A magyar jakobinusok iratai, vol. 2 (Budapest: Akadémiai Kiadó, 1952), 682.

${ }^{66}$ M. Szilágyi, "Ein ungarischer Schriftsteller im Theresianischen Wien: Georg Bessenyei," in Wiener Archivforschungen. Festschrift für den Ungarischen Archivdelegierten in Wien, István Fazekas, ed. Cziráki Zs., et al. (Vienna: Institut für ungarische Geschichtsforschung in Wien, 2014), 287-94.

${ }^{67}$ Kissné Bognár, Magyarországi diákok, 335-45; A magyar testőrségek névkönyve, 61-404. 


\section{Список литературы}

Хаванова О.В. Заслуги отцов и таланты сыновей: венгерские дворяне в учебных заведениях монархии Габсбургов, 1746-1784. - Санкт-Петербург: Алетейя, 2006. - 439 с.

Ballagi A. A magyar királyi testőrség története, különös tekintettel irodalmi müködésére. Pest: Légrády testvérek, 1872. - 446 old.

Cerman I. Habsburgischer Adel und Aufklärung. Bildungsverhalten des Wiener Hofadels im 18. Jahrhundert. - Stuttgart: Franz Steiner Verlag, 2010. - 303 S. (Contubernium. Tübinger Beiträgezur Universitäts- und Wissenschaftsgeschichte. Bd. 72).

Ember Gy. A m. kir. Helytartótanács ügyintézésének története 1724-1848. - Budapest: M. Kir. Országos Levéltár, 1940. - 298 old.

Fónagy Z. A nemesi birtokviszonyok az úrbérrendezés korában. - Budapest: MTA BTK TTI, 2013. - 1558 old. (Magyar Történelmi Emlékek. Adattárak).

Gestrich A. Die galizischen adeligen Leibgarden am Wiener Hof. Ein Beispiel habsburgischer Inklusions-politik nach den Teilungen Polen-Litauens // Militär und Gesellschaft in der Frühen Neuzeit. - 2013. - Jg. 17. - No. 1. - S. 41-64.

Irmen H.J. Die Protokolle der Wiener Freimaurerloge "Zur Wahren Eintracht" (1781-1785). Wien: Peter Lang, 1994. - 451 S. (Schriftenreihe der Internationalen Forschungsstelle Demokratische Bewegungen in Mitteleuropa 1770-1850. Bd. 15).

Khavanova $O$. Der ungarische Adel am Wiener Theresianum im 18. Jahrhundert: die sozialen und kulturellen Grenzen einer politischen Nation // Österreichisch-ungarische Beziehungen auf dem Gebiet des Hochschulwesens - Osztrák-magyar felsőoktatási kapcsolatok / Szerk. Zs.K. Lengyel, J.Zs. Nagy, G. Ujváry. - Székesfehérvár: Kodolányi János Főiskola; Budapest: Eötvös Loránd Tudományegyetem Könyvtára, 2010. - 107-122. old.

Khavanova $O$. Eine universitäre Lehrveranstaltung als universales Instrument: Joseph von Sonnenfels und die administrative Elite der Habsburgermonarchie // Die Anatomie frühneuzeitlicher Imperien. Herrschaftsmanagement jenseits von Staat und Nation / Hrsg. von S. Wendehorst. - Berlin; München; Boston: Walter de Gruyter, 2015. - S. 103-129.

Khavanova $O$. Fascination with Uniform? Choosing between Military and Civil Careers in the Eighteenth-Century Habsburg Monarchy // Hungarian Studies. - 2018. - Vol. 32. - No. 1. - P. 113130.

Kissné Bognár K. Magyarországi diákok a bécsi tanintézetekben, 1526-1789. - Budapest: Eötvös Loránd Tudományegyetem Levéltára, 2004. - 552 old.

Kökényesi Zs. Das Bild und die Repräsentation des Theresianums in der Öffentlichkeit des 18. Jahrhunderts // Wiener Geschichtsblätter. - 2015. - Jg. 70. - No. 3. - S. 263-280.

Kökényesi Zs. Egyháziak, katonák, nemesek. Eszéki, károlyvárosi és selmecbányai szabadkőműves páholyok tagjai 1785-ben // Polymatheia. - 2020. - 3-4. sz. - 53-85. old.

Kökényesi Zs. Helyzetértékelés és konszolidációs javaslatok. Egy 1711 körüli emlékirat tanulságai // Fons. - 2020. - No. 4. - S. 291-304.

Lüdin M. Die Leibgarden am Wiener Hof: PhD Diss. - Universität Wien, 1965 (рукопись).

Málnási Ö. Gróf Csáky Imre bíbornok élete és kora (1672-1732). - Kalocsa: Csáky család kiadása, 1933. - 327 old.

Mraz G. Johann Baptist Skall - Geschichte, Administration und Einrichtung der königlich ungarischen adeligen Leibgarde // Forscher - Gestalter - Vermittler. Festschrift Gerald Schlag / Hrsg. Von W. Gürtler. - Eisenstadt: Amt der Burgenländischen Landesregierung, 2001. - S. 239252. 
Paskovits E. Die erste Arcièrenleibgarde Seiner Majestät des Kaisers und Königs. Ein Rückblick auf ihre 150-jährige Geschichte. - Wien: Selbstverlag der k. k. Ersten Arcièrenleibgarde, 1914. - $238 \mathrm{~S}$.

Rakuscha G. Die Leibgarden am österreichischen Herrscherhof: PhD Diss. - Universität Wien, 1981. - 223 B1. (рукопись).

Rosenstrauch-Königsberg E. Freimaurerei im josephinischen Wien. Aloys Blumauers Weg vom Jesuiten zum Jakobiner. - Wien; Stuttgart: W. Braumüller, 1975. - 376 S. (Wiener Arbeiten zur deutschen Literatur. Bd. 6).

Shek Brnardic T. The Enlightened Officer at Work: The Educational Projects of the Bohemian Count Franz Joseph Kinsky (1739-1805): PhD thesis. - Central European University, 2004. (рукопись) - 338 p.

Szijártó I. The Rákóczi Revolt as a Successful Rebellion // Resistance, Rebellion and Revolution in Hungary and Central Europe: Commemorating 1956 / edited by L. Péter, M. Rady. London: Hungarian Cultural Centre, 2008. - 67-76. old.

Szilágyi M. Ein ungarischer Schriftsteller im theresianischen Wien: Georg Bessenyei // Wiener Archivforschungen. Festschrift für den Ungarischen Archivdelegierten in Wien, István Fazekas / Hrsg. von Zs. Cziráki, et al. - Wien: Institut für ungarische Geschichtsforschung in Wien, 2014. S. 287-294.

Urrisk-Obertyński R.M. Die k. u. k. Leibgarden am österreichisch-ungarischen Hof 15181918. - Gnas: Weishaupt, 2004. - 303 S.

Varga J. Magyarországi diákok a Habsburg Birodalom kisebb egyetemein és akadémiáin 1560-1789. - Budapest: Eötvös Loránd Tudományegyetem Levéltára, 2004. - 590 old. (Magyarországi diákok egyetemjárása az újkorban. 12. sz.)

\section{References}

Ballagi, A. A magyar királyi testőrség története, különös tekintettel irodalmi müködésére. Pest: Légrády testvérek, 1872.

Cerman, I. Habsburgischer Adel und Aufklärung. Bildungsverhalten des Wiener Hofadels im 18. Jahrhundert. Contubernium. Tübinger Beiträge zur Universitäts- und Wissenschaftsgeschichte, Bd. 72. Stuttgart: Franz Steiner Verlag, 2010.

Ember, Gy. A m. kir. Helytartótanács ügyintézésének története 1724-1848. Budapest: M. Kir. Országos Levéltár, 1940.

Fónagy, Z. A nemesi birtokviszonyok az úrbérrendezés korában. Magyar Történelmi Emlékek. Adattárak. Budapest: MTA BTK TTI, 2013.

Gestrich, A. "Die galizischen adeligen Leibgarden am Wiener Hof. Ein Beispiel habsburgischer Inklusions-politik nach den Teilungen Polen-Litauens." Militär und Gesellschaft in der Frühen Neuzeit, Jg. 17, Heft 1 (2013): 41-64.

Irmen, H.J. Die Protokolle der Wiener Freimaurerloge "Zur Wahren Eintracht” (1781-1785). Schriftenreihe der Internationalen Forschungsstelle Demokratische Bewegungen in Mitteleuropa 1770-1850, Bd. 15. Vienna: Peter Lang, 1994.

Khavanova, O. "Der ungarische Adel am Wiener Theresianum im 18. Jahrhundert: die sozialen und kulturellen Grenzen einer politischen Nation." In Österreichisch-ungarische Beziehungen auf dem Gebiet des Hochschulwesens - Osztrák-magyar felsőoktatási kapcsolatok, edited by 
Zs.K. Lengyel, J.Zs. Nagy, G. Ujváry, 107-22. Székesfehérvár: Kodolányi János Főiskola; Budapest: Eötvös Loránd Tudományegyetem Könyvtára, 2010.

Khavanova, O. "Eine universitäre Lehrveranstaltung als universales Instrument: Joseph von Sonnenfels und die administrative Elite der Habsburgermonarchie." In Die Anatomie frühneuzeitlicher Imperien. Herrschaftsmanagement jenseits von Staat und Nation, edited by S. Wendehorst, 103-29. Berlin; Munich; Boston: Walter de Gruyter, 2015.

Khavanova, O. "Fascination with Uniform? Choosing between Military and Civil Careers in the Eighteenth-Century Habsburg Monarchy." Hungarian Studies, vol. 32, no. 1 (2918): 113-30.

Khavanova, O. Zaslugi ottsov $i$ talanty synovei: vengerskie dvoryane $v$ uchebnykh zavedeniyakh monarkhii Gabsburgov, 1746-1784 [Fathers' merits and sons' talents: Hungarian nobles in educational institutions of the Habsburg Monarchy, 1746-1784]. St Petersburg: Aleteiya, 2006. (In Russian)

Kissné Bognár, K. Magyarországi diákok a bécsi tanintézetekben, 1526-1789. Budapest: Eötvös Loránd Tudományegyetem Levéltára, 2004.

Kökényesi, Zs. "Das Bild und die Repräsentation des Theresianums in der Öffentlichkeit des 18. Jahrhunderts.” Wiener Geschichtsblätter, vol. 70, no. 3 (2015): 263-80.

Kökényesi, Zs. "Egyháziak, katonák, nemesek. Eszéki, károlyvárosi és selmecbányai szabadkőmüves páholyok tagjai 1785-ben.” Polymatheia, sz. 3-4 (2020): 53-85.

Kökényesi, Zs. "Helyzetértékelés és konszolidációs javaslatok. Egy 1711 körüli emlékirat tanulságai." Fons, no. 4 (2020): 291-304.

Lüdin, M. Die Leibgarden am Wiener Hof. PhD diss. University of Vienna, 1965.

Málnási, Ö. Gróf Csáky Imre bíbornok élete és kora (1672-1732). Kalocsa: Csáky család kiadása, 1933.

Mraz, G. "Johann Baptist Skall - Geschichte, Administration und Einrichtung der königlich ungarischen adeligen Leibgarde." In Forscher - Gestalter - Vermittler. Festschrift Gerald Schlag, edited by W. Gürtler, 239-52. Eisenstadt: Amt der Burgenländischen Landesregierung, 2001.

Paskovits, E. Die erste Arcièrenleibgarde Seiner Majestät des Kaisers und Königs. Ein Rückblick auf ihre 150-jährige Geschichte. Vienna: Selbstverlag der k. k. Ersten Arcièrenleibgarde, 1914.

Rakuscha, G. Die Leibgarden am österreichischen Herrscherhof. PhD diss. University of Vienna, 1981.

Rosenstrauch-Königsberg, E. Freimaurerei im josephinischen Wien. Aloys Blumauers Weg vom Jesuiten zum Jakobiner. Wiener Arbeiten zur deutschen Literatur, Bd. 6. Wien; Stuttgart: W. Braumüller, 1975.

Shek Brnardić, T. The enlightened officer at work: the educational projects of the Bohemian count Franz Joseph Kinsky (1739-1805). PhD thesis. Central European University, 2004.

Szijártó, I. "The Rákóczi Revolt as a successful rebellion." In Resistance, Rebellion and Revolution in Hungary and Central Europe: Commemorating 1956, edited by L. Péter and M. Rady, 67-76. London: Hungarian Cultural Centre London, 2008.

Szilágyi, M. "Ein ungarischer Schriftsteller im Theresianischen Wien: Georg Bessenyei." In Wiener Archivforschungen. Festschrift für den ungarischen Archivdelegierten in Wien, István Fazekas, edited by Cziráki Zs. et al., 287-94. Vienna: Institut für ungarische Geschichtsforschung in Wien, 2014.

Urrisk-Obertyński, R.M. Die k. u. k. Leibgarden am österreichisch-ungarischen Hof 15181918. Gnas: Weishaupt, 2004. 
Varga, J. Magyarországi diákok a Habsburg Birodalom kisebb egyetemein és akadémiáin 1560-1789. Budapest: Eötvös Loránd Tudományegyetem Levéltára, 2004. (Magyarországi diákok egyetemjárása az újkorban, 12. sz.)

\section{Информация об авторе}

Жолт Кёкенеши - PhD (история), научный сотрудник, https://orcid.org/0000-00033964-1043, kokenyesi.zsolt@btk.elte.hu, кафедра истории раннего Нового времени Института истории, Университет им. Л. Этвеша (1088 Будапешт, Múzeum körút 6-8)

\section{Information about the author}

Zsolt Kökenyesi - PhD in Historical Sciences, Research Fellow, https://orcid.org/00000003-3964-1043, kokenyesi.zsolt@btk.elte.hu, Institute of Historical Studies, Department of Early Modern History, Eötwös Loránd University (1088 Budapest, Múzeum körút 6-8)

Статья поступила в редакцию 18.12.2020; одобрена после рецензирования 22.01.2021; принята к публикации 25.01.2021.

The article was submitted 18.12.2020; approved after reviewing 22.01.2021; accepted for publication 25.01.2021. 